\title{
Genome-scale analysis of DNA methylation in lung adenocarcinoma and integration with mRNA expression
}

\author{
Suhaida A. Selamat, ${ }^{1}$ Brian S. Chung, ${ }^{1}$ Luc Girard, ${ }^{2}$ Wei Zhang, ${ }^{2}$ Ying Zhang, ${ }^{3}$ \\ Mihaela Campan, ${ }^{1}$ Kimberly D. Siegmund, ${ }^{3}$ Michael N. Koss, ${ }^{4}$ Jeffrey A. Hagen, ${ }^{5}$ \\ Wan L. Lam, ${ }^{6}$ Stephen Lam, ${ }^{6}$ Adi F. Gazdar, ${ }^{2}$ and Ite A. Laird-Offringa ${ }^{1,7}$ \\ ${ }^{1}$ Department of Surgery, Department of Biochemistry and Molecular Biology, Norris Comprehensive Cancer Center, Keck School of \\ Medicine, University of Southern California, Los Angeles, California 90089-9176, USA; ${ }^{2}$ The Hamon Center for Therapeutic Oncology \\ Research and Department of Pathology, University of Texas Southwestern Medical Center, Dallas, Texas 75390, USA; ${ }^{3}$ Department \\ of Preventive Medicine, Keck School of Medicine, University of Southern California, Los Angeles, California 90089-9176, USA; \\ ${ }^{4}$ Department of Pathology, Keck School of Medicine, University of Southern California, Los Angeles, California 90089-91 76, USA; \\ ${ }^{5}$ Department of Surgery, Keck School of Medicine, University of Southern California, Los Angeles, California 90089-9176, USA; \\ ${ }^{6}$ BC Cancer Research Center, BC Cancer Agency, Vancouver, BC V521 L3, Canada
}

\begin{abstract}
Lung cancer is the leading cause of cancer death worldwide, and adenocarcinoma is its most common histological subtype. Clinical and molecular evidence indicates that lung adenocarcinoma is a heterogeneous disease, which has important implications for treatment. Here we performed genome-scale DNA methylation profiling using the Illumina Infinium HumanMethylation27 platform on 59 matched lung adenocarcinoma/non-tumor lung pairs, with genome-scale verification on an independent set of tissues. We identified 766 genes showing altered DNA methylation between tumors and non-tumor lung. By integrating DNA methylation and mRNA expression data, we identified 164 hypermethylated genes showing concurrent down-regulation, and 57 hypomethylated genes showing increased expression. Integrated pathways analysis indicates that these genes are involved in cell differentiation, epithelial to mesenchymal transition, RAS and WNT signaling pathways, and cell cycle regulation, among others. Comparison of DNA methylation profiles between lung adenocarcinomas of current and never-smokers showed modest differences, identifying only LGALS4 as significantly hypermethylated and down-regulated in smokers. LGALS4, encoding a galactoside-binding protein involved in cell-cell and cell-matrix interactions, was recently shown to be a tumor suppressor in colorectal cancer. Unsupervised analysis of the DNA methylation data identified two tumor subgroups, one of which showed increased DNA methylation and was significantly associated with KRAS mutation and to a lesser extent, with smoking. Our analysis lays the groundwork for further molecular studies of lung adenocarcinoma by identifying novel epigenetically deregulated genes potentially involved in lung adenocarcinoma development/progression, and by describing an epigenetic subgroup of lung adenocarcinoma associated with characteristic molecular alterations.
\end{abstract}

[Supplemental material is available for this article.]

Lung cancer is the leading cause of cancer-related death worldwide (Jemal et al. 2011). In many countries, adenocarcinoma has surpassed squamous carcinoma as the most common histological subtype of lung cancer, and it is also the most common histological subtype in women, Asians, and never-smokers (Toh et al. 2006). Lung adenocarcinoma is increasingly recognized as a clinically and molecularly heterogeneous disease. This is exemplified by recent reclassifications based on pathology and patient survival (Travis et al. 2011), the increasing number of clinical trials demonstrating targeted treatments that specifically benefit patients defined by molecular subtypes such as EGFR, KRAS, BRAF, and ERBB2 mutations and EML4-ALK fusions (Pao et al. 2004, 2005a,b; Pao and Girard 2011), as well as observed prognostic gene expression signature profiles (Bhattacharjee et al. 2001; Beer et al. 2002; Larsen

\footnotetext{
${ }^{7}$ Corresponding author E-mail ilaird@usc.edu

Article published online before print. Article, supplemental material, and publication date are at http://www.genome.org/cgi/doi/10.1101/gr.132662.111.
}

et al. 2007). DNA methylation-based profiling has also confirmed the existence of epigenetic subtypes in several cancers (Issa 2004; Li et al. 2010; Noushmehr et al. 2010; Hinoue et al. 2012). Promoter DNA methylation, which is associated with gene silencing, can regulate gene expression in a myriad of biological and pathological processes, including lung cancer (Jones 2002; Belinsky 2004; Kerr et al. 2007; Brock et al. 2008; Risch and Plass 2008). Unlike genetic mutations, DNA methylation is an inherently reversible change, and therefore is of great interest as an active target of drug development (Esteller 2003; Rodriguez-Paredes and Esteller 2011).

While previous studies have profiled DNA methylation in lung adenocarcinoma (Shiraishi et al. 2002; Divine et al. 2005; Tsou et al. 2005, 2007; Toyooka et al. 2006; Tessema and Belinsky 2008; Christensen et al. 2009; Goto et al. 2009; Kubo et al. 2009), they have either been limited in the number of samples or genes assayed, focused on a mix of lung cancer histologies, thereby limiting the ability to identify subtypes, or lacked expression studies that allow the potential function of DNA methylation alterations to be determined. To address these issues, here we analyzed 59 lung 
adenocarcinoma tumors and matched adjacent non-tumor lung (NTL) tissues. Because adenocarcinoma is the most common lung cancer subtype found in never-smokers, it was important to ensure that cancers from smokers and never-smokers would both be included. Thus, we chose the cases so that approximately half of the tumors were from patients who were never-smokers. Using the Illumina Infinium HumanMethylation 27 platform, we interrogated the DNA methylation status of $27,578 \mathrm{CpG}$ dinucleotides spanning 14,475 genes. Focusing on genes differentially methylated in tumor vs. non-tumor lung, we integrated mRNA expression data to identify DNA methylation events with potential functional significance. We verified our findings using an independent set of 28 lung adenocarcinomas and matched adjacent NTL, as well as validated select DNA methylation data using an alternative assay, MethyLight. Lastly, we used both supervised and unsupervised analyses of the DNA methylation data to identify subgroups within the tumors.

\section{Results}

Genome-scale DNA methylation profiles were obtained for 59 lung adenocarcinomas and matched adjacent NTL tissue (Table 1). Thirty tumors were from never-smokers (defined here as less than 100 cigarettes in a lifetime), while 29 were from current smokers. Before any statistical tests were conducted, we inspected the data for the presence of substantial confounding batch effects due to the separate plates or chips (Leek et al. 2010). We did not observe any such effects (see Supplemental Fig. 1; Methods). One NTL sample was eliminated for quality-control reasons (see Methods); 117 samples were thus further analyzed (as outlined in Supplemental Fig. 2).

\section{Identification of differentially methylated regions in lung adenocarcinoma}

We first performed an exploratory two-dimensional (2D) hierarchical clustering of the top 5000 probes that varied most across the 117 samples (Fig. 1A). The DNA methylation profiles of tumors and NTL resulted in separate clusters, with the exception of one NTL sample (3022_N), indicating a substantial difference in DNA methylation profiles between the tumor and non-tumor samples. We next performed a locus-by-locus differential DNA methylation analysis of tumors vs. NTL to identify differentially methylated

Table 1. Characteristics of subjects and tumors

\begin{tabular}{|c|c|c|c|c|}
\hline Characteristic & Classes & $\begin{array}{c}\text { Never- } \\
\text { smokers }\end{array}$ & $\begin{array}{l}\text { Current } \\
\text { smokers }^{\mathrm{a}}\end{array}$ & Fisher $P$ \\
\hline \multirow[t]{2}{*}{ Sex } & Male & 7 & 7 & 1.00 \\
\hline & Female & 23 & 22 & \\
\hline \multirow[t]{2}{*}{ Race } & Asian & 21 & 1 & $6.15 \times 10^{-8}$ \\
\hline & White & 9 & 28 & \\
\hline \multirow{2}{*}{ Age $^{\mathrm{b}}$} & $<68$ & 10 & 15 & 0.19 \\
\hline & $\geq 68$ & 20 & 14 & \\
\hline \multirow[t]{2}{*}{ Stage } & Early (Stages I-II) & 23 & 23 & 1.00 \\
\hline & Late (Stages III-IV) & 7 & 6 & \\
\hline \multirow[t]{2}{*}{ KRAS mutation } & WT & 27 & 10 & $1.10 \times 10^{-5}$ \\
\hline & Mutant & 3 & 19 & \\
\hline \multirow[t]{2}{*}{ EGFR mutation } & WT & 13 & 29 & $6.19 \times 10^{-7}$ \\
\hline & Mutant & 17 & 0 & \\
\hline \multirow{2}{*}{ STK11 mutation ${ }^{c}$} & WT & 27 & 22 & 0.052 \\
\hline & Mutant & 1 & 7 & \\
\hline
\end{tabular}

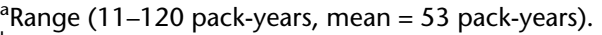

${ }^{\mathrm{b}}$ Range (39-86 yr, mean $\left.=68 \mathrm{yr}\right)$.

'STK11 mutation status was unavailable for two never-smoker subjects. probes. Using our criteria of $Q<0.05$ and a minimum median $\beta$-value difference of $20 \%$, we identified 681 probes (520 genes) that were significantly hypermethylated in tumors, and 275 probes (247 genes) that were significantly hypomethylated (Fig. 1B; Supplemental Table 1). Some of our most hypermethylated loci include HOX genes, specifically HOXB4, HOXA9, and HOXA7. Seventeen different $H O X$ genes passed our strict cutoffs, many passing with multiple probes, supporting previous observations of widespread DNA methylation of the Polycomb complex-targeted HOX genes (Shiraishi et al. 2002; Rauch et al. 2007). Some of our most hypomethylated loci include CASP8 and TNFRSF10A, both involved in TNF-receptor-mediated apoptosis (Boldin et al. 1996; Wang and El-Deiry 2003). To investigate the categories of genes exhibiting altered DNA methylation, we performed a DAVID functional annotation analysis (Huang da et al. 2009). The differentially hypermethylated set of genes was significantly enriched in GO biological processes including regulation of transcription, embryonic morphogenesis, cell-cell signaling, and cell surface receptor-linked signal transduction, while the differentially hypomethylated set was significantly enriched in processes including epidermal cell differentiation, epithelial cell differentiation, and defense response (Benjamini-Hochberg $[\mathrm{BH}]$ adjusted $p<0.05$ ).

For the differentially methylated probes, we also investigated whether or not they corresponded to genes with associated CpG islands and were located in promoters (Fig. 1C). Sixty-four percent of probes hypermethylated in tumors corresponded to genes with associated CpG islands, vs. only $7 \%$ of probes hypomethylated in tumors (Fisher $p<2.2 \times 10^{-16}$ ). In addition, $77 \%$ of probes hypermethylated in tumors were located in promoter regions (defined as the region $1 \mathrm{~kb}$ upstream or downstream of the nearest transcription start site), vs. only $68 \%$ of hypomethylated probes (Fisher $p<0.005$ ). Our findings support previous observations showing significant differences between the characteristics of genes that gain DNA methylation during tumorigenesis, vs. those that lose DNA methylation (Ohm et al. 2007; Schlesinger et al. 2007). One gene, CDH13-known to be repressed in lung cancer (Sato et al. 1998; Toyooka et al. 2003; Selamat et al. 2011)—was represented by nine probes on this platform and was present in both the hypermethylated and hypomethylated lists (Supplemental Figs. 3, 4). Three $C D H 13$ probes were included in our set of the 5000 most variable probes. Of these, two were statistically significantly hypermethylated in tumors, while one was hypomethylated. The former were both located in the promoter region of the gene, and four additional probes in this region also showed hypermethylation in tumors, although they did not meet the strict criteria for significance. The hypomethylated probe was not located in or near a CpG island and resided in intron 1 of the gene, $>10 \mathrm{~kb}$ from the transcription start site. The two additional probes in this region showed trends of hypomethylation, although they did not reach statistical significance in the discovery analysis. Thus, the CDH13 gene appears to be characterized by widespread differential and bidirectional changes in DNA methylation in lung adenocarcinoma vs. the adjacent NTL. This exemplifies the recent observation that methylation gain in the promoter can be coupled with methylation loss in the gene body (Berman et al. 2012).

To ensure that our findings were not dependent on the specific population analyzed, we performed an additional differential DNA methylation analysis on an independent sample set of 28 lung adenocarcinomas and 27 NTL (Supplemental Table 2), using the same Infinium platform. By applying identical statistical criteria, we identified 313 significantly hypermethylated genes and 85 significantly hypomethylated genes in this verification set (Sup-

\section{Genome Research \\ www.genome.org}


A

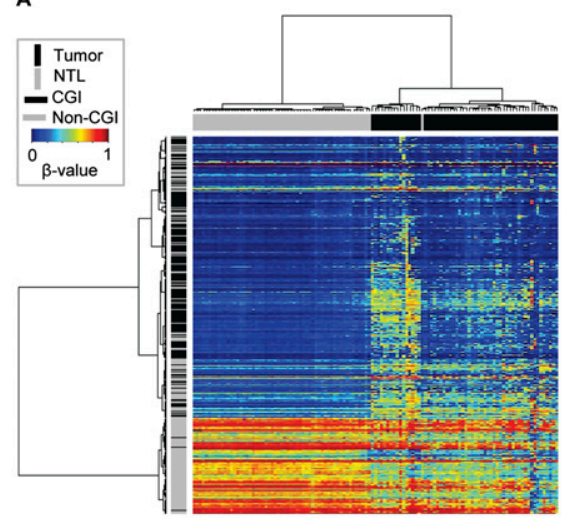

C

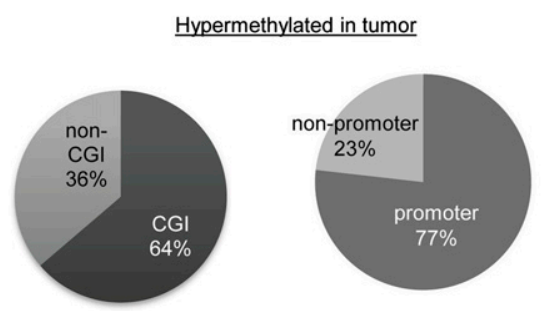

Hypomethylated in tumor
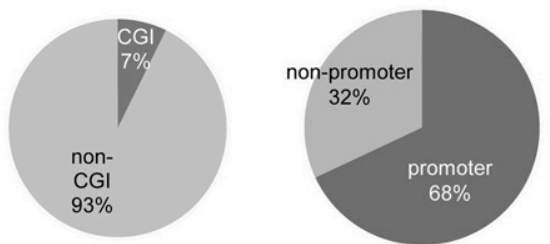

B

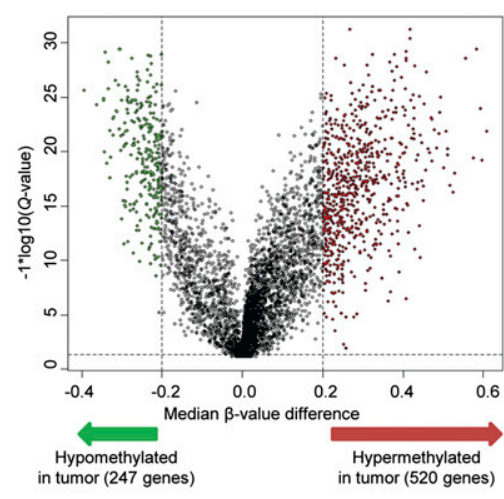

D

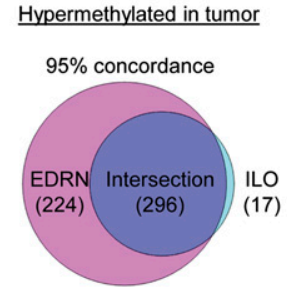

Hypomethylated in tumor

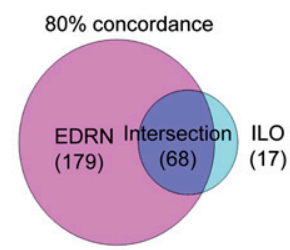

Figure 1. Identification of DNA methylation differences between lung adenocarcinoma and NTL. ( $A$ ) Two-dimensional hierarchical clustering was performed using the 5000 most variable Infinium DNA methylation probes across all samples $(n=117)$. Probes are in rows; samples are in columns. Note that both hypermethylation and hypomethylation in tumors compared with NTL is seen, and that hypomethylation largely occurs outside of $\mathrm{CpG}$ islands. (B) Volcano plot of the differential DNA methylation analysis. ( $X$-axis) Median $\beta$-value difference (median tumor-median NTL); $(y$-axis) $Q$-values for each probe $\left(-1 \times \log _{10}\right.$ scale). (Vertical dotted lines) $20 \%$ change in $\beta$-values; (horizontal dotted line) the significance cutoff. One gene, $C D H 13$, showed both significant hypermethylation and hypomethylation (see text and Supplemental Figs. 3 and 4). (C) Proportions of probes from genes with associated CpG islands (CGI) and probe locations, categorized as promoter ( $\pm 1 \mathrm{~kb}$ from TSS) or nonpromoter regions. $(D)$ Overlap of significant unique gene lists using an independent sample set (see also Supplemental Figs. 2 and 5).

plemental Fig. 5A,B). While the smaller number of genes that passed our criteria is expected due to the smaller sample size of the verification set, we found that $95 \%$ of the hypermethylated genes and $80 \%$ of hypomethylated genes in the verification set had been identified in our discovery analysis (Fig. 1D), supporting our initial findings. To provide technical validation of our observations, we assessed the DNA methylation levels of 12 genes using the real-time PCR-based MethyLight technique on DNA from 26 tumor/NTL pairs, of which 10 tumors and 13 NTL samples were also part of the Infinium verification data set (Supplemental Fig. 5C). These 12 genes were chosen based on significance, functional relevance, and assay design compatibility. Differences in the observed absolute levels of DNA methylation might be expected due to the more stringent nature of the MethyLight assay, which requires multiple fully methylated CpG dinucleotides in the region covered by the primers and probe. In spite of this, all genes tested except one (SOCS2) that were found to be hypermethylated in the Infinium study were confirmed to be significantly hypermethylated in the verification set tumors. In addition, both hypomethylated genes tested (Supplemental Fig. 5C, right panels, FAM83A and $S F N$ ) were confirmed to be statistically significantly hypomethylated in tumors.

\section{Identification of potentially functionally relevant DNA methylation changes in lung adenocarcinoma}

To identify those DNA methylation changes with concomitant changes in gene expression, we integrated the gene expression profiles and DNA methylation profiles of the EDRN tumor and NTL tissue samples. We were able to examine gene expression levels for 709 out of 766 of the differentially methylated genes. An exploratory hierarchical clustering of the expression levels of just these 709 genes completely separated out tumors vs. NTL (Fig. 2A). Using a $\mathrm{BH}$-adjusted $P$-value cutoff of $0.05,349$ genes were differentially expressed. Of these, 164 genes were statistically significantly hypermethylated and down-regulated (23\%), while 57 genes (8\%) were significantly hypomethylated and up-regulated (Fig. 2B; Supplemental Table 3), suggesting that abnormal DNA methylation might have functional consequences in approximately one-third of the genes showing differential DNA methylation between tumor and NTL. We used Ingenuity Pathways Analysis to investigate which gene networks might be affected by the aberrant DNA methylation of these 221 genes. The top two gene networks identified involved cell differentiation, on the one hand, and MAPK signaling/cell cycle control, on the other (Fig. 2C). Prominent in the first network were phosphoinositide-3-kinase (PIK3) complex members, JUN transcription factors of the AP1 family, transforming growth factor $\beta$, and $W N T$ signaling pathway members. Epigenetic interactions with histones $\mathrm{H} 3$ and $\mathrm{H} 4$ were also seen in the first network. In the second network, genes of the MAPK and FGF families, and CCNA1 and 2 (cyclin A1 and 2) were central. Analysis of the top functional categories of deregulated genes pointed to cellular movement and development, tissue development, and cellular growth and proliferation (Fig. 2D). We then used the NextBio database (http://www.nextbio.com) (Kupershmidt et al. 2010) to identify biosets (uploaded data sets) that were significantly associated with our list of 221 genes for which DNA methylation changes were significantly inversely correlated with changes in expression. We found highly statistically significant overlaps (all $p<1.0 \times 10^{-20}$ ) with several previously published gene expression studies comparing lung adenocarcinoma to nontumor lung (Fig. 2E; Supplemental Fig. 6A-C; Wrage et al. 2009; Hou et al. 2010; Lu et al. 2010). One hundred and seven of the 221 


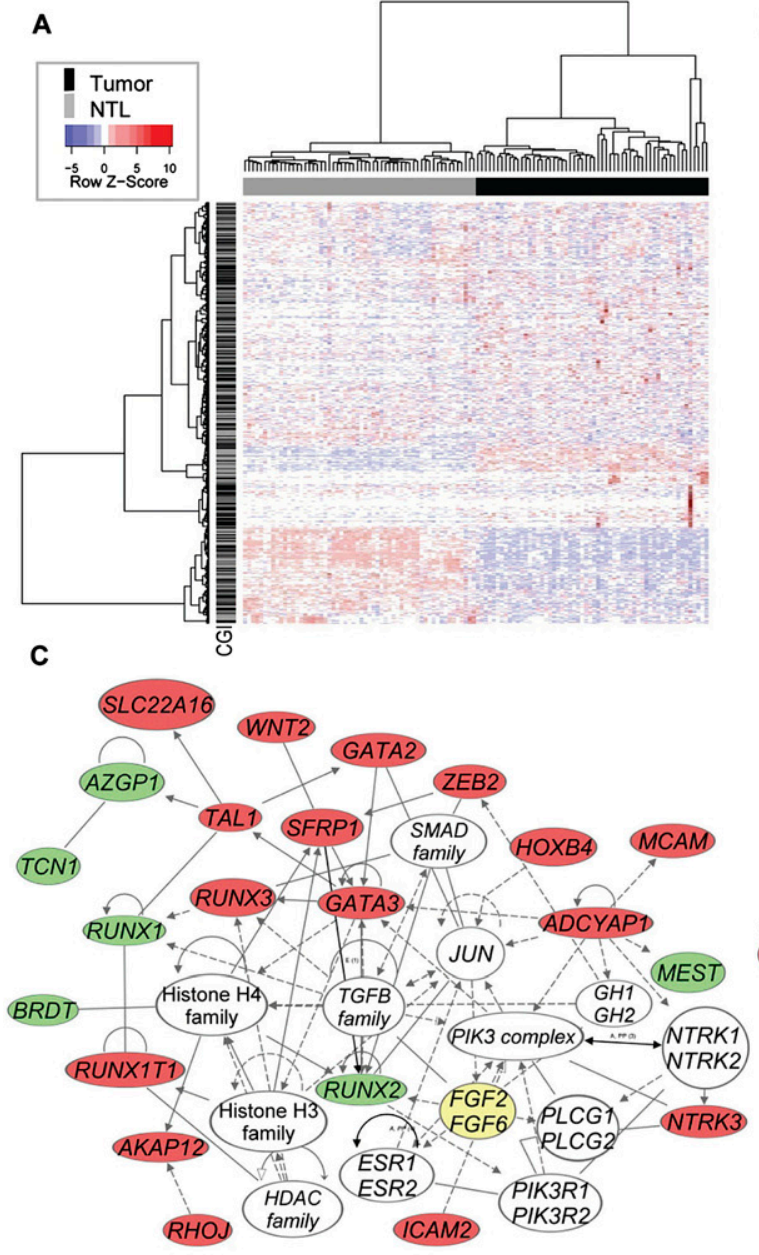

D

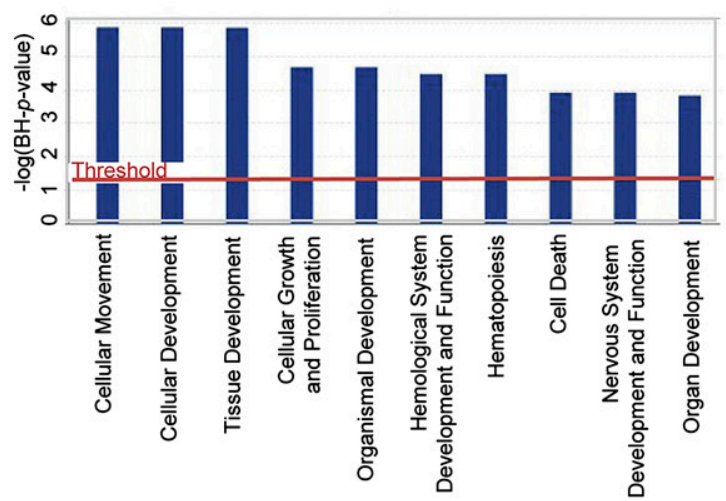

B

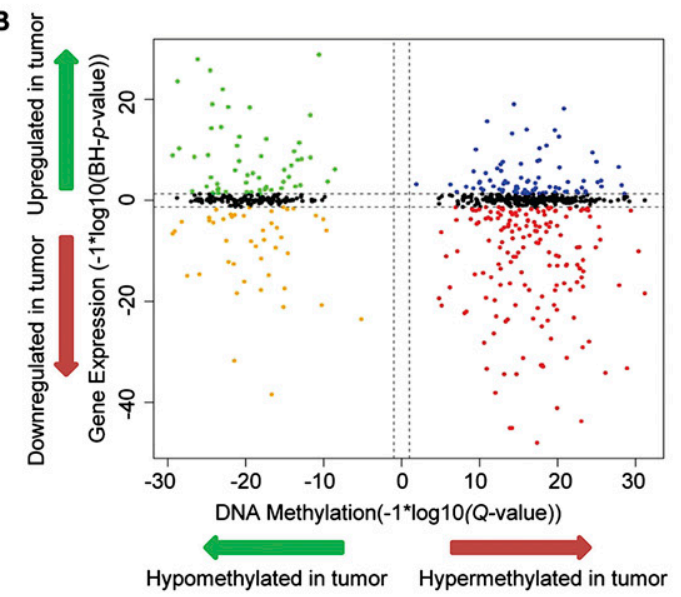

E

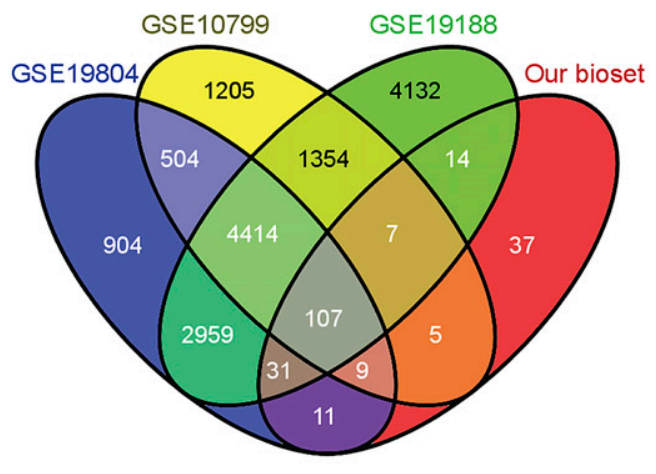

Figure 2. Identification of genes showing coordinately changed DNA methylation and gene expression. (A) Two-dimensional hierarchical clustering with 1061 probes corresponding to 709 genes across all tumors $(n=58)$ and NTL $(n=58)$. Rows represent probes; columns are samples. (B) Starburst plot integrating differential DNA methylation and gene expression analyses. (X-axis) DNA methylation Q-values $\left(-1 \times \log _{10} \mathrm{scale}\right) ;(y$-axis) BH adjusted $P$-values $\left(-1 \times \log _{10}\right.$ scale). Indicated are genes that are hypermethylated and down-regulated in tumors (red); hypomethylated and up-regulated in tumors (green); hypermethylated and up-regulated in tumors (blue); or hypomethylated and down-regulated in tumors (orange). (C) Top gene networks identified through integrative pathways analysis of significant DNA methylation changes associated with significant inverse gene expression changes. Indicated are genes that are hypomethylated and up-regulated in tumors (green) or hypermethylated and down-regulated in tumors (red). (Solid lines) Direct interaction; (dashed lines) indirect interaction. $(D)$ The most significantly enriched biological process categories within genes showing significant DNA methylation changes associated with significant inverse gene expression changes. (E) Venn diagram of NextBio analysis showing the overlap of our bioset (genes showing significant DNA methylation changes in conjunction with significant inverse gene expression changes) with the three most highly correlated NextBio biosets (see also Supplemental Fig. 6).

\section{Genome Research}

www.genome.org 
genes were found in all of the top three most correlated biosets (48\%), while 184 of the 221 genes ( $83 \%$ ) were found in at least one of the top three most correlated biosets. Additionally, our 221 genes were highly correlated with two colorectal cancer DNA methylation studies (Supplemental Fig. 6D,E; Hinoue et al. 2012; YH Kim and YS Kim, unpubl.).

To identify the top changing genes, we applied a twofold cutoff to the average change in gene expression (Fig. 3A), finding 45 genes that were coordinately hypermethylated and downregulated in tumors, and 16 genes that were coordinately hypomethylated and up-regulated (Tables $2 \mathrm{~A}, 2 \mathrm{~B}$ ). Thus, $\sim 9 \%$ of the genes identified as hypermethylated in lung adenocarcinoma are also down-regulated on average more than twofold in the same tissues, a percentage similar to that found in colorectal cancer (Hinoue et al. 2012). In a more global integration analysis using all genes in common between the DNA methylation and gene expression platforms, we identified these same genes as our top candidates for showing DNA methylation-based deregulation (data not shown). For many of the genes we identified, little to nothing is known about DNA methylation-based deregulation in cancer. In addition to those genes showing inverse relationships between DNA methylation and gene expression changes, five genes were found to be hypermethylated but up-regulated in tumors, while 10 genes were found to be hypomethylated and down-regulated (Supplemental Table 4). We attempted to characterize the different groups of genes by examining whether or not they were associated with CpG islands and/or promoter regions. We found a statistically significant association between group membership and CpG island status (Fisher $p<0.001$ ) (Fig. 3B); genes for which DNA methylation increased were significantly associated with CpG islands, regardless of the direction of the gene expression difference. We found no statistically significant difference between group membership and whether or not probes were located in the promoter region (Fisher $p<0.44$ ) (Fig. 3B). Scatterplots illustrate the negative correlation between DNA methylation and gene expression for select genes as well as the distinct distribution of tumor and NTL sample values (Fig. 3C).

Examination of the clinical characteristics of the tumors (Table 1) yielded the expected statistically significant correlations of smoking with KRAS mutations and never-smoking with EGFR mutations (Sun et al. 2007). To examine the overall difference in DNA methylation between tissues from smokers and never smokers, we performed a correlation analysis, which showed very similar DNA methylation profiles in both groups, although the correlation for NTL was highest (Fig. 4A,D). We then performed a locus-by-locus differential DNA methylation analysis of smoker vs. never-smoker tissue (tumors as well as NTL) to identify differentially methylated probes. While NTL showed no significant differential DNA methylation between smokers and never-smokers, six genes were statistically significantly different between the tumor tissues of smokers and never-smokers (Fig. 4B,E). IRF8, IHH, LGALS4, IL18BP, and VTN were hypermethylated in current smoker tumors, while KLF11 was hypomethylated (Supplemental Table 5). Only LGALS4 showed a statistically significant corresponding down-regulation in gene expression in current smoker tumors (BH $p<0.0069)$. A scatterplot of DNA methylation vs. gene expression for LGALS4, which encodes a galactoside-binding protein involved in cell-cell and cell-matrix interactions, demonstrates the dramatic hypermethylation and down-regulation of the gene in current smoker tumors (Fig. 4C).

One problem with the studied sample collection was a bias in the ethnic composition (Table 1); only one of the 29 smokers was Asian, whereas 21/30 neversmokers were Asian. To address this bias, we performed a multiple linear regression analysis and found that even with adjustment for race, all five genes that were significantly hypermethylated in smokers remained significant. KLF11 hypomethylation, however, did not. We examined LGALS4, the only gene showing significantly altered gene expression, more closely. When we performed a linear regression analysis with adjustment for race as well as KRAS and EGFR status, the correlation between LGALS4 and smoking

Figure 3. Genes showing the most significant changes in DNA methylation and gene expression $(A)$ Three-dimensional starburst plot of 709 genes, integrating significant changes in DNA methylation ( $x$-axis) and gene expression ( $z$-axis), with a mean twofold or greater change in gene expression ( $y$-axis) Colors are as in Figure 2B. (B) Presence of $\mathrm{CpG}$ islands and probe locations for genes exhibiting hyperor hypomethylation and up- or down-regulation. $(C)$ Correlation plots of DNA methylation vs. gene expression in tumors and normal tissues for select genes. 
Table 2A. Top hypermethylated and down-regulated genes in lung adenocarcinoma

\begin{tabular}{|c|c|c|}
\hline $\mathrm{HUGO}^{\mathrm{a}}$ & HUGO gene name ${ }^{a}$ : function ${ }^{b}$ & References $^{c}$ \\
\hline$A B C A 3^{d}$ & ATP-binding cassette, subfamily A, member 3: ATP-binding cassette transporter & Schimanski et al. 2010 \\
\hline$A C V R L 1^{\mathrm{d}}$ & Activin A receptor type II-like 1: TGF-beta receptor, serine/threonine kinase & Hu-Lowe et al. 2011 \\
\hline ADCY4 & Adenylate cyclase 4: Membrane-bound adenylyl cyclase & Rui et al. 2008 \\
\hline$A L D H 1 A 2$ & Aldehyde dehydrogenase 1 family, member A2: Retinoic acid synthesis & Kim et al. 2005 \\
\hline C1orf87 & Chromosome 1 open reading frame 87: Undetermined & None available \\
\hline & Complement component 7: Component of complement system & Oka et al. 2001 \\
\hline $\mathrm{CDH13}$ & Cadherin 13: Cell adhesion & Selamat et al. 2011 \\
\hline CDO1 & Cysteine dioxygenase, type I: Regulator of cellular cysteine concentrations & Dietrich et al. 2010 \\
\hline CLDN5 & Claudin 5: Integral membrane protein, tight junction component & Sato et al. 2003 \\
\hline CLEC14A & C-type lectin domain family 14, member A: Undetermined & Mura et al. 2012 \\
\hline CLEC1A & C-type lectin domain family 1, member A: Cell adhesion, cell-cell signaling & None available \\
\hline CSF3R & Colony stimulating factor 3 receptor: Cell proliferation, differentiation, survival & Wang et al. 2010 \\
\hline CTNNAL1 & Catenin (cadherin-associated protein), alpha-like 1: Modulates Rho signaling & Noordhuis et al. 2011 \\
\hline CYYR1 & Cysteine/tyrosine-rich 1: Undetermined & Vitale et al. 2007 \\
\hline DOCK2 ${ }^{\mathrm{d}}$ & Dedicator of cytokinesis 2: Cytoskeletal rearrangements, activate RAC1, RAC2 & Nishihara et al. 2002 \\
\hline EFCAB1 & EF-hand calcium binding domain 1: Undetermined & None available \\
\hline EFEMP1 ${ }^{\mathrm{d}}$ & EGF containing fibulin-like extracellular matrix protein 1 : Binds $E G F, E G F R$; cell adhesion, migration & Yue et al. 2007 \\
\hline EPB41L3 & Erythrocyte membrane protein band 4.1-like 3: Meningiomas pathogenesis & Kikuchi et al. 2005 \\
\hline GATA2 & GATA binding protein 2: Transcriptional activator & Acosta et al. 2011 \\
\hline HBA1 & Hemoglobin, alpha 1: Oxygen transport from lung to peripheral tissues & None available \\
\hline$H D C$ & Histidine decarboxylase: Converts L-histidine to histamine & Suzuki-Ishigaki et al. 2000 \\
\hline$H O X A 5^{\mathrm{d}}$ & Homeobox A5: transcription factor; development, up-requlates $p 53$ & Shiraishi et al. 2002 \\
\hline ICAM2 & Intercellular adhesion molecule 2: Cell adhesion interaction & Hiraoka et al. 2011 \\
\hline$J A M 2^{\mathrm{d}}$ & Junctional adhesion molecule 2 : Tight junctions & Oster et al. 2011 \\
\hline LTC4S & Leukotriene C4 synthase: Production of leukotriene C4 & Sakhinia et al. 2006 \\
\hline$M A L^{\mathrm{d}}$ & Mal, T-cell differentiation protein: Integral membrane protein, trafficking & Lind et al. 2007 \\
\hline MAMDC2 & MAM domain containing 2: Undetermined & None available \\
\hline$N D R G 2^{\mathrm{d}}$ & NDRG family member 2: Dendritic/neuron cell differentiation, anti-tumor activity & Piepoli et al. 2009 \\
\hline$P R X$ & Periaxin: Peripheral nerve myelin maintenance & Lehtonen et al. 2004 \\
\hline RHOJ & Ras homolog gene family, member J: GTP-binding protein; cell morphology & Kaur et al. 2011 \\
\hline SCARA5 & Scavenger receptor class A, member 5: Ferritin receptor & Huang et al. 2010 \\
\hline SCN4B & Sodium channel, voltage-gated, type IV, beta: Modulate channel gating kinetics & Chioni et al. 2009 \\
\hline SLC15A3 & arrier family 15 memher 3. Proton oligonentide cotransnorter & Ibragimova et al. 2010 \\
\hline SNRPN & Small nuclear ribonucleoprotein polypeptide N: Tissue-specific alternative RNA processing & Kohda et al. 2001 \\
\hline SOCS $2^{\mathrm{d}}$ & Suppressor of cytokine signaling 2: Cytokine transduction, negative regulator in $\mathrm{GH} / \mathrm{IFG} 1$ signaling & Wikman et al. 2002 \\
\hline SOSTDC1 & Sclerostin domain containing 1: BMP antagonist; Wnt and TGF-beta signaling & Clausen et al. 2011 \\
\hline SOX17 & SRY (sex determining region Y)-box 17: Transcription regulator; Wht signaling inhibitor & Zhang et al. 2008 \\
\hline SPARCL1 & SPARC-like 1 (hevin): Undetermined & Bendik et al. 1998 \\
\hline SPON1 ${ }^{\mathrm{d}}$ & Spondin 1, extracellular matrix protein: Cell adhesion & Pyle-Chenault et al. 2005 \\
\hline TEK & TEK tyrosine kinase, endothelial: Endothelial cell proliferation, differentiation & Mazzieri et al. 2011 \\
\hline TM6SF1 & Transmembrane 6 superfamily member 1 : Undetermined & Tao et al. 2011 \\
\hline TMEM204 & Transmembrane protein 204: Cell adhesion and cellular permeability & Shimizu et al. 2011 \\
\hline TOX2 & TOX high mobility group box family member 2: Transcriptional activator & None available \\
\hline TUBB6 & Tubulin, beta 6: Major constituent of microtubules & Leandro-Garcia et al. 2010 \\
\hline ZEB2 & Zinc finger E-box binding homeobox 2: Transcriptional inhibitor, interacts with activated SMADs & Rodenhiser et al. 2008 \\
\hline
\end{tabular}

First report of DNA methylation in lung cancer shown in bold.

${ }^{a}$ Human Genome Organization nomenclature.

${ }^{\mathrm{b}}$ Gene function from GeneCards website, http://www.genecards.org/.

CPreviously reported studies in order of relevance: DNA methylation in lung cancer, DNA methylation in non-lung cancer, known in lung cancer, known in non-lung cancer.

${ }^{d}$ Tested in independent population using MethyLight (see Supplemental Fig. 5).

remained statistically significant. In addition, a comparison of all Asian vs. all Caucasian tumors did not identify LGALS4 as significantly differentially methylated between the two populations. Lastly, in an analysis limited to only Caucasian tumors (nine neversmokers vs. 28 current-smokers), LGALS4 was found to be differentially methylated (Wilcoxon $p<0.009$, median $\beta$-value difference $=0.22$ ). These observations support an association between LGALS4 hypermethylation in lung adenocarcinoma and smoking.

The limited number of significant differences between current and never-smoker lung adenocarcinomas and their highly similar global DNA methylation profiles (Fig. 4A) prompted further investigation. We examined 30 genes that had previously been reported to show differences between smokers and never-smokers. Of these, 14 genes showed statistically significant differences in
DNA methylation, but only one gene, $C D K N 2 A$, showed a median $\beta$-value difference of $>20 \%$ between current smokers and neversmokers (Supplemental Table 6). Our results therefore suggest that smoking status did not greatly influence the DNA methylation profiles of the tumors in our collection.

Class discovery: Identification of DNA methylation subgroups in lung adenocarcinoma

We performed an unsupervised analysis of the entire 59-tumor set to identify any intrinsic DNA methylation-based subclasses that could then be investigated in relation to known clinical features. We used either the top 5000 most variable probes within the tumors (Fig. 5A) or the 766 differentially methylated genes (Supplemental Fig. 7A,C).

\section{Genome Research www.genome.org}


Table 2B. Top hypomethylated and up-regulated genes in lung adenocarcinoma

\begin{tabular}{|c|c|c|}
\hline $\mathrm{HUGO}^{\mathrm{a}}$ & HUGO gene name ${ }^{a}$ : function ${ }^{b}$ & References $^{c}$ \\
\hline AGR2 & Anterior gradient homolog 2: Proto-oncogene; cell migration, differentiation and growth & Pizzi et al. 2012 \\
\hline AIM2 & Absent in melanoma 2: Tumor suppressor; represses NF-kappa-B transcription & Pedersen et al. 2011 \\
\hline CFB & Complement factor B: Component of complement system & None available \\
\hline FAM $83 A^{\mathrm{d}}$ & Family with sequence similarity 83 member A: Undetermined & Jensen et al. 2008 \\
\hline GRB7 & Growth factor receptor-bound protein 7: Integrin signaling pathway, cell migration & Tanaka et al. 2006 \\
\hline HABP2 & Hyaluronan binding protein 2: Activates coagulation factor VII & Wang et al. 2002 \\
\hline KRT8 & Keratin 8: Cellular structure; signal transduction & Sartor et al. 2011 \\
\hline$\angle A M B 3$ & Laminin, beta 3: Interaction with ECM, cell migration, attachment & Sathyanarayana et al. 2003 \\
\hline MX2 & Myxovirus (influenza virus) resistance 2: GTPase & Kobayashi et al. 2004 \\
\hline PROM2 & Prominin 2: Organization of plasma membrane & Rohan et al. 2006 \\
\hline$R A B 25$ & RAB25, member RAS oncogene family: Cell survival, migration, and proliferation & Goldenring and Nam 2011 \\
\hline$S F N^{\mathrm{d}}$ & Stratifin: Epithelial cell growth; stimulates Akt/mTOR pathway; p53-regulated inhibitor of $\mathrm{G}_{2} / \mathrm{M}$ progression & Osada et al. 2002 \\
\hline SPDEF & $\begin{array}{l}\text { SAM pointed domain containing ETS transcription factor: Androgen-independent } \\
\text { transactivator of PSA, SERPINB5 }\end{array}$ & Ghadersohi et al. 2004 \\
\hline TCN1 & Transcobalamin I: Vitamin B12-binding protein & Remmelink et al. 2005 \\
\hline TM4SF4 & Transmembrane $4 \mathrm{~L}$ six family member 4: Cell proliferation, growth, motility & None available \\
\hline ZNF750 & Zinc finger protein 750: Undetermined & None Available \\
\hline
\end{tabular}

First report of DNA methylation in lung cancer shown in bold.

${ }^{a}$ Human Genome Organization nomenclature.

${ }^{b}$ Gene function from GeneCards website, http://www.genecards.org/.

CPreviously reported studies in order of relevance: DNA methylation in lung cancer, DNA methylation in non-lung cancer, known in lung cancer, known in non-lung cancer.

${ }^{d}$ Tested in independent population using MethyLight (see Supplemental Fig. 5).

Both hierarchical clustering analyses identified two distinct clusters, with only two tumors changing memberships between the two clustering approaches. Comparison of DNA methylation of the 5000 most variable probes among the tumor tissues showed considerable hypermethylation: 962 probes (753 genes) were significantly hypermethylated in Cluster 1 vs. Cluster 2 , and only one gene was significantly more methylated in Cluster 2 vs. Cluster 1 (RUNX1) (Fig. 5B; Supplemental Table 7). We investigated whether this hypermethylation was tumor-specific and how it related to the probes previously identified as differentially methylated between all tumors vs. all NTL (Fig. 5C,D). Two hundred and sixty-two probes overlapped between the two groups, representing CpGs that were differentially methylated between all tumors and NTL, and that showed significant additional hypermethylation in the tumors of Cluster 1. Notably, 694 probes that had been identified as differentially methylated between all tumors and NTL did not overlap with probes differentially methylated between the two clusters. These probes comprised ones hypomethylated in the tumors as well as probes that were hypermethylated in tumors, but not additionally hypermethylated in Cluster 1 (Fig. 5D, blue dots). This suggests that the hypermethylation seen in Cluster 1 is not a global phenomenon but appears to occur in a particular group of genes. Lastly, 701 probes (red dots) were differentially methylated in Cluster 1 vs. 2 but were not identified as differentially methylated between all tumors vs. NTL. These probes were hypermethylated in tumor vs. NTL samples from Cluster 1, but not from Cluster 2 (Fig. 5E). To determine whether the differential DNA methylation of these latter probes might be of functional relevance, we examined the expression levels of these probes in Cluster 1 tumors vs. Cluster 1 NTL, identifying 13 genes that were concordantly down-regulated and hypermethylated, and three genes that were hypermethylated and up-regulated (Supplemental Table 8). Of interest was the hypermethylation and down-regulation of two genes encoding cell adhesion molecules, junctional adhesion molecule 3 (JAM3) and claudin 11 (CLDN11). Hypermethylation-based silencing of CLDN11 has been implicated in gastric cancer metastasis (Agarwal et al. 2009). Also notable was the hypermethylated and down-regulated gene GFRA1, encoding a membrane protein that interacts with the RET tyrosine kinase (Leppanen et al. 2004). Interestingly, chromosomal translocations that activate RET were recently described in lung adenocarcinoma (Ju et al. 2012; Lipson et al. 2012). The significance of GFRA1 deregulation and other Cluster 1-specific gene deregulatory events is worthy of further investigation, because it might point to patient subgroup-specific targets for epigenetic therapy.

Investigating the relationship of the two clusters to their clinical and genetic properties, we found no significant differences in clinical stage, age, gender, race, STK11 or EGFR mutation status, or survival between the two clusters (all $p>0.05$ ) (Fig. 5A; Supplemental Fig. 7B). However, we did observe statistically significant positive associations between Cluster 1 membership and KRAS mutation and smoking status (Fig. 5F,G). These results held true with both hierarchical clustering approaches. We determined that within KRAS mutants, there was no association between cluster membership and smoking (Fisher $p=0.21$ ), whereas within current smokers, there was a significant association between KRAS mutation and Cluster 1 (Fisher $p=0.02$ ), indicating that KRAS rather than smoking is associated with the more heavily methylated cluster. We found no significant association between the types of KRAS mutations and cluster membership (Fisher's $p<0.49$ ), although this analysis was limited by the modest number of samples in this study. To further investigate the relationship between KRAS mutational status and cluster membership, we subdivided Cluster 1 and 2 tumors by KRAS mutational status and compared the median DNA methylation $\beta$-values among these groups. The median $\beta$-values for the KRAS mutant vs. wild-type tumors was well-correlated in both clusters (Supplemental Fig. $8 \mathrm{~A}, \mathrm{~B})$. In addition, Cluster 1 tumors showed higher median $\beta$-values in numerous CpGs irrespective of the KRAS mutational status (Supplemental Fig. 8C,D). These observations suggest that while KRAS mutational status is positively associated with Cluster 1 membership, it is not the driver behind Cluster 1-specific DNA methylation. 

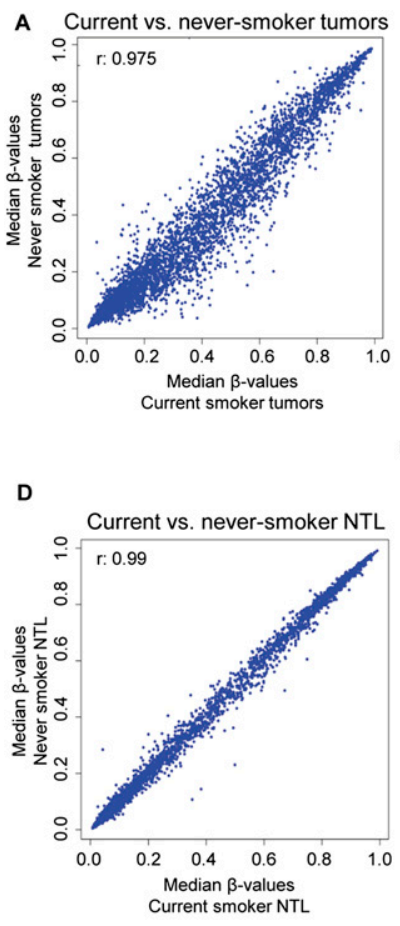

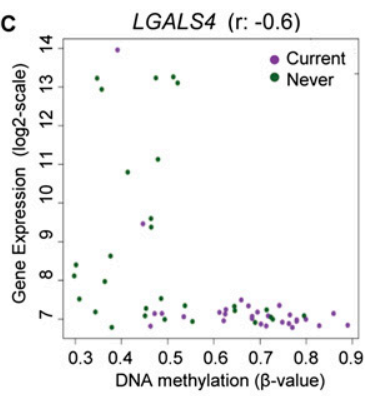

DNA methylation ( $\beta$-value)

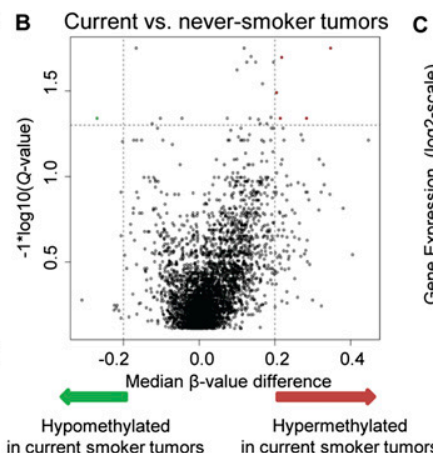

$\begin{array}{rr}\text { in current smoker tumors } & \text { in current smoker } \\ \text { ( } 1 \text { gene) } & \text { (5 genes) }\end{array}$

$E$

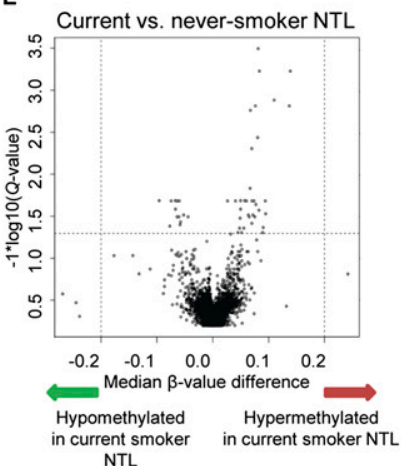

Figure 4. Identification of DNA methylation differences between lung adenocarcinoma tumors and NTL with regard to smoking. (A) Correlation matrix of median $\beta$-values of tumors from current smokers vs. never-smokers, with the Spearman rho correlation given in the top left corner. (B) Volcano plot of the differential DNA methylation analysis between tumors from smokers and never-smokers. (Vertical dotted lines) $20 \%$ change in $\beta$-values; (horizontal dotted line) the significance cutoff. (C) Correlation plot of DNA methylation vs. expression for LGALS4. The Spearman rho correlation coefficient is provided on top. $(D)$ Correlation matrix of median $\beta$-values of NTL from current smokers vs. never-smokers, with the Spearman rho correlation given in the top left corner. $(E)$ Volcano plot of the differential DNA methylation analysis between NTL from smokers and never-smokers. (Vertical dotted lines) $20 \%$ change in $\beta$-values; (horizontal dotted line) the significance cutoff. No significant DNA methylation differences are seen between NTL from smokers and never-smokers.

We next investigated whether the differential DNA methylation between the two clusters could be due to differential expression of proteins known to influence DNA methylation levels. We found no significant differences in expression levels of DNMT1, DNMT3A, DNMT3B, DNMT3L, TET1, TET2, and TET3 between the two clusters (Supplemental Fig. 9). However, when we examined global gene expression differences between the two clusters, we identified 36 genes that were statistically significantly differentially expressed (unrelated to DNA methylation), with seven genes meeting a twofold cutoff (Fig. 5H; Supplemental Table 9). Of these, three were cytokines (CXCL9, CXCL10, and CXCL14), while another gene, PHLDA1, encodes a regulator of IGF1-mediated apoptosis (Toyoshima et al. 2004).

\section{Discussion}

Using genome-level interrogation of DNA methylation, we identified 766 genes showing significant differential DNA methylation in cancer tissues. These genes may be useful to develop biomarkers for diagnostic or prognostic purposes. For example, the comparison of lung adenocarcinoma DNA methylation profiles with those of white blood cells and other types of cancers (e.g., through The Cancer Genome Atlas; http://cancergenome.nih.gov/), could lead to the development of improved DNA methylation-based blood biomarkers specific for lung adenocarcinoma (Esteller et al. 1999; Usadel et al. 2002). To distinguish DNA methylation events of potential functional significance ("driver events") from those that do not biologically contribute to tumorigenesis ("passenger events"), we integrated the DNA methylation data with gene expression profiles of the same tumors. One hundred and sixty-four genes were concordantly hypermethylated and down-regulated, and 57 genes were concordantly hypomethylated and upregulated. Ingenuity Pathways Analysis identified two top deregulated networks: one involved in epithelial-to-mesenchymal transition, the other centered on growth factor signal transduction and cell cycle control. More stringent filtering of genes requiring a minimal mean twofold change in expression yielded 45 hypermethylated and down-regulated genes, including novel methylated genes such as $A B C A 3$, an ATP-binding cassette transporter protein with a critical role in lung development and surfactant metabolism in humans (Shulenin et al. 2004) and mice (Cheong et al. 2007). Also of interest are SOX17, a canonical WNT antagonist previously shown to be functionally hypermethylated in breast and colorectal cancers (Zhang et al. 2008; Fu et al. 2010), and TMEM204, a transmembrane protein that plays a role in cell adhesion and is hypermethylated and down-regulated in pancreatic cancer (Shimizu et al. 2011). To our knowledge, this is the first report of the epigenetic deregulation of these and numerous other genes in lung cancer.

The top hypomethylated and up-regulated gene, FAM $83 A$, has been demonstrated previously to be specifically up-regulated in lung cancer, especially in lung adenocarcinomas (Li et al. 2005). Expression of FAM $83 A$ has been used to detect circulating cancer cells in the peripheral blood of lung cancer patients (Liu et al. 2008). FAM83A was also shown to be epigenetically regulated in an in vitro model of arsenic-mediated malignant transformation (Jensen et al. 2008). Also of interest are $A G R 2, K R T 8$, and SFN. AGR2 is a known proto-oncogene recently confirmed to be overexpressed in lung adenocarcinoma (Pizzi et al. 2012), and has been shown to promote cell proliferation and migration in several different cancers (Ramachandran et al. 2008; Vanderlaag et al. 2010; Park et al. 2011). KRT8, encoding keratin 8 , was previously reported to be up-regulated in lung adenocarcinoma (Wikman et al. 2002); and SFN, encoding stratifin, has been reported to be overexpressed in early invasive lung adenocarcinoma (Shiba-Ishii et al. 2011). Investigating the link between loss of methylation and increased expression of these genes will be important, given the increasing use of epigenetic therapies in cancer treatment.

In addition to genes showing an inverse correlation between DNA methylation and expression, we also identified several genes that were coordinately hypermethylated and up-regulated, or

\section{Genome Research} www.genome.org 
A

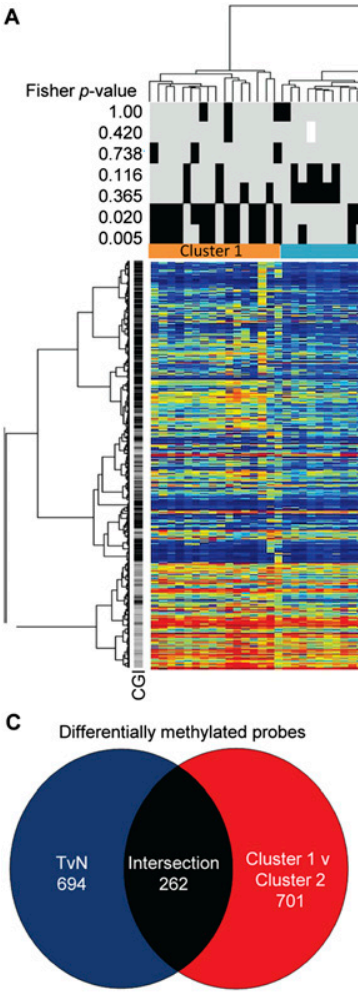

$\mathbf{F}$

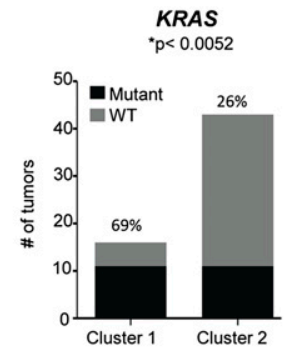

B

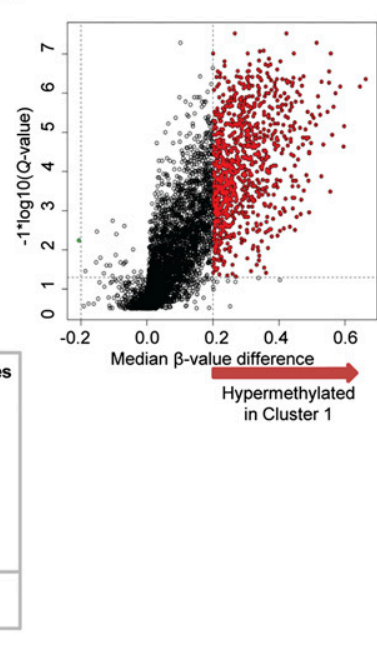

complex. The Illumina Infinium HumanMethylation27 platform is based on probe hybridization and single nucleotide extension, and therefore levels of DNA methylation observed with a particular probe are highly dependent on whether the probe is located within or outside of a CpG island and its proximity to the transcription start site of a gene (Brenet et al. 2011; van Vlodrop et al. 2011). Additionally, the identification of long-range DNA methylation, or spreading of DNA methylation (Clark 2007), as well as roles for DNA methylation on the border or just outside CpG islands, termed "shores" and "shelves" (Irizarry et al. 2009), DNA methylation-regulated alternate transcripts (Maunakea et al. 2010), the role of DNA methylation in chromatin arrangement and organization of the genome (Berman et al. 2012), miRNA regulation (Lopez-Serra and Esteller 2012), and even gene silencing by nonCpG island DNA methylation (Han et al. 2011) add increasing intricacy to the relationship between DNA methylation and gene regulation. The new Illumina Infinium HumanMethylation 450 bead array, whole-genome bisulfite-sequencing, and RNA-seq will be able to shed more light onto these possibilities (Berman et al. 2012).

Distinct mutational and gene expression differences between lung adenocarcinomas of smokers and never-smokers have been frequently noted (e.g., Belinsky et al. 2002; Toyooka et al. 2003; Pao et al. 2004, 2005b; Sun et al. 2007; Landi et al. 2008). Previous candidate-gene studies (Belinsky et al. 2002; Pulling et al. 2003) were recapitulated in our study albeit with smaller differences. It should be considered that the second most common form of lung cancer, squamous cell carcinoma, occurs predominantly in smokers, while adenocarcinoma is the most common lung cancer histology in never-smokers. Our study focuses exclusively on lung adenocarcinoma, and the modest differences we detect may therefore be due to different histological compositions as well as to differences in methodology. Two recent studies suggest no simple relationship between tobacco smoke carcinogens and DNA methylation. In a study comparing peripheral blood DNA methylation profiles of smokers and nonsmokers, only one differentially methylated locus was found (Breitling et al.

hypomethylated and down-regulated. While these two groups of genes do not fit into the classical paradigm of DNA methylation regulation, increasing evidence from recent deep sequencing studies show that DNA methylation regulation may be more
2011). An in vitro study of human lung cells chronically exposed to a tobacco carcinogen also showed little to no effect on DNA methylation profiles in treated vs. untreated cells (Tommasi et al. 2010). In our genome-scale supervised approach, we noted only six sig- 
nificantly differentially methylated genes between smokers and never-smokers, and of these only LGALS4 showed a corresponding down-regulation in gene expression in current smoker tumors. LGALS4 has been implicated in several cancers, including gastric, colon, and sinusoidal adenocarcinomas (Sakakura et al. 2005; Tripodi et al. 2009; Watanabe et al. 2011). Recently, a mechanism for the involvement of LGALS4 as a tumor suppressor in colorectal cancer was proposed involving the WNT signaling pathway (Satelli et al. 2011). This is especially interesting given the well-established role that $W N T$ signaling plays in the development of lung cancer (Mazieres et al. 2005; Nguyen et al. 2009). Importantly, previous studies have suggested that the WNT pathway is involved in cigarette smoke-induced tumorigenesis (Lemjabbar-Alaoui et al. 2006; Hussain et al. 2009). To our knowledge, this is the first report of differential expression of LGALS4 between smoker and never-smoker lung tumors and of DNA methylation as a potential regulator of LGALS4 expression. Functional validation of LGALS4 regulation in lung adenocarcinoma is a highly interesting avenue of future investigation.

Genome-wide DNA methylation profiling has led to increased knowledge of epigenetic subtypes of colorectal cancer, glioblastoma, and multiple myeloma, among others (Noushmehr et al. 2010; Walker et al. 2011; Hinoue et al. 2012). The best-established DNA methylation-based subgroup is that of $\mathrm{CpG}$ island methylator phenotype (CIMP), first identified in colorectal cancer (Toyota et al. 1999). CIMP tumors possess high frequency and levels of cancerspecific DNA methylation at loci that show little or no methylation in non-CIMP tumors. CIMP sometimes shows differences in patient survival and is closely associated with $B R A F$ activating mutations, but this does not appear to drive CIMP (Teodoridis et al. 2008). The existence of CIMP has been suggested in NSCLC (Marsit et al. 2006; Suzuki et al. 2006) using a very limited number of genes. However, another study did not support this conclusion (Vaissiere et al. 2009). Our use of 27,578 probes enabled a more thorough examination of DNA methylation, and we find no evidence for classic CIMP in lung cancer. An additional epigenotype, termed CIMP-low, has been reported and confirmed in several independent populations of colorectal tumors using different methodologies (Ogino et al. 2006; Shen et al. 2007; Yagi et al. 2010; Hinoue et al. 2012). CIMP-low exhibits moderately high levels of DNA hypermethylation at a subset of CIMP-associated loci, and in each study was found to be associated with KRAS mutation. Although the current lung adenocarcinoma study is limited by a modest sample size, we too observe an epigenetic subtype of lung adenocarcinoma with higher DNA methylation levels that is associated with KRAS mutation. In 2006, a higher methylation index in KRAS mutant tumors in comparison to KRAS wild-type tumors was described (Toyooka et al. 2006). However, like CIMP-low in colorectal cancer, KRAS mutations appear not to drive this epigenetic subgroup, and a more complex molecular mechanism may cause the observed epigenetic heterogeneity (Hinoue et al. 2012). The hypermethylated cluster was also associated (albeit more weakly) with smoking status, which is not surprising given the fact that KRAS mutations are most common in smokers (Ahrendt et al. 2001).

To further characterize the CIMP-low cluster, we identified genes that show cluster and tumor-specific DNA methylationbased down-regulation, including GFRA1. These genes, which might constitute new DNA-methylation-based deregulated driver genes characteristic for a subset of lung adenocarcinomas, merit further exploration. In addition, we identified seven genes showing statistically significant expression changes of at least twofold, unrelated to DNA methylation. Three out of the seven genes were cytokines recently shown to play a role in tumorigenesis (Andersson et al. 2011), while PHLDA1, a regulator of IGF1-mediated apoptosis (Toyoshima et al. 2004), has recently been suggested to be a putative epithelial stem cell marker in the human intestine (Sakthianandeswaren et al. 2011). The role of cytokines in tumorigenesis is of increasing interest (Dranoff 2004; Li et al. 2011), and the connection between DNA methylation, cytokines, and cancer is an intriguing avenue of investigation (Yoshikawa et al. 2001; Galm et al. 2003; Niwa et al. 2005; Sunaga et al. 2012). While we do not find a survival difference between the two DNA methylation-based clusters, further characterization of the identified molecular differences may lead to the development of new treatment strategies targeted to this subgroup of tumors.

In summary, our DNA methylation profiling of 59 lung adenocarcinomas and matched adjacent non-tumor lung tissue accomplished three goals: (1) the identification of numerous new cancer-specific DNA methylation changes that can be pursued as potential lung adenocarcinoma biomarkers; (2) the identification of potentially functional DNA methylation changes that may constitute driver alterations in lung adenocarcinoma; and (3) the identification of an epigenetic subgroup of lung adenocarcinoma with higher levels of DNA methylation that is reminiscent of CIMP-low in colorectal cancer, is correlated with KRAS mutation, and shows specific gene expression alterations. Our observations lay the groundwork for further diagnostic and mechanistic studies of lung adenocarcinoma that could lead to improvements in detection, patient classification, and therapy.

\section{Methods}

\section{Study samples}

The Early Detection Research Network (EDRN)/Canary Foundation tissue collection consisted of 60 lung adenocarcinoma tumors and matched adjacent histologically confirmed non-tumor lung (NTL), collected after surgery. Forty-five adenocarcinoma/NTL pairs were obtained from the Vancouver General Hospital (Vancouver, Canada) and 15 adenocarcinoma/NTL pairs from the British Columbia Cancer Agency Tumor Tissue Repository (Vancouver, Canada, BCCA Research Ethics Board \#H09-00008). Thirty subjects were never-smokers (defined as less than 100 lifetime cigarettes), and 30 were current smokers (average 53 pack-years, range 11-120 pack-years). One tumor sample was excluded after pathology review later revealed it to be a large cell carcinoma. Subject characteristics for the remaining 59 subjects are detailed in Table 1. For verification of DNA methylation profiling, an independent sample set of 28 lung adenocarcinomas and 27 NTL was used. Subject characteristics for the validation population are detailed in Supplemental Table 2. Of these, 21 tumor and 20 NTL de-identified samples were purchased from the Ontario Tumor Bank (OTB, Ontario, Canada), while seven tumors and seven NTL were collected at the University Hospital at the University of Southern California (USC IRB protocol \#HS-06-00447). For MethyLight verification of selected probes, OTB samples were used (26 tumors and 26 NTL), of which 25 pairs were matched. Ten of the tumors and 13 of the NTL samples examined by MethyLight were the same tissues used for the genome-wide verification. EDRN/Canary samples were assessed by an experienced pathologist (A.F.G.), while the verification samples were assessed by a separate expert lung pathologist (M.N.K.). All sample collections were performed conforming to protocols approved by the appropriate local Institutional Review Boards and were acquired with informed consent. The identities of the subjects were not made available to the laboratory investigators. 


\section{DNA methylation data production}

DNA was extracted by proteinase $\mathrm{K}$ digestion following manual microdissection from slides prepared from fresh frozen tissue blocks. The DNA was then bisulfite-converted using the EZ DNA Methylation kit (Zymo Research) with a modification to the manufacturer's protocol in which samples were cycled 16 times for $30 \mathrm{sec}$ at $90^{\circ} \mathrm{C}$ and $1 \mathrm{~h}$ at $50^{\circ} \mathrm{C}$. The Illumina Infinium HumanMethylation27 BeadChip assays were performed by the USC Epigenome Center according to the manufacturer's protocols (Illumina). This assay generates DNA methylation data for $27,578 \mathrm{CpG}$ dinucleotides covering 14,473 unique genes. DNA methylation levels are reported as $\beta$-values, calculated from mean methylated (M) and unmethylated (U) signal intensities for each locus for each sample using the formula $[\beta=\mathrm{M} /(\mathrm{M}+\mathrm{U})]$. Probes with detection $P$-values of $>0.05$ were deemed not significantly different from background noise and were labeled "NA." Data for all samples are publicly available at the EDRN Public Portal (http://www.cancer. gov/edrn). MethyLight experiments were performed as previously described (Campan et al. 2009). MethyLight measurements are represented as percentage methylated reference (PMR), defined by the GENE:ALU ratio of a sample, wherein $A L U$ refers to a reference primer/probe combination that lacks CpGs and is designed to bind to a subset of $A L U$ repeat sequences (Weisenberger et al. 2006), divided by the GENE:ALU ratio of M.SsSI-treated reference DNA. This results in a PMR range of $0-100$, where a PMR of 0 indicates no detectable DNA methylation and a PMR of 100 represents fully methylated molecules. Occasionally, a PMR of $>100$ can be observed, which may result when the reference DNA was not fully methylated at a particular site. To minimize this, the same batch of reference DNA that has been exhaustively enzymatically methylated is used throughout the experiments (Selamat et al. 2011). Previously published MethyLight primer/probe sets were used for the $S F N$ and MAL locus and the $A L U$ reference (Weisenberger et al. 2006; Noushmehr et al. 2010). Other MethyLight primer/probe sequences are detailed in Supplemental Table 10.

\section{DNA methylation data analysis}

Data analyses were performed using R (R Development Core Team 2011) and Bioconductor (Gentleman et al. 2004). The analyses of 120 tissue samples necessitated conducting the experiment with the samples randomized and spread over two bisulfite treatment plates and 16 Infinium BeadChips. Batch effect investigations were performed as recommended (Leek et al. 2010) and are illustrated in Supplemental Figure 1. Three tissue samples were excluded from analyses: one tumor/NTL tissue pair (07L36_T/N) found to be a large cell carcinoma instead of a lung adenocarcinoma and one NTL sample (3023_N) for which correlation analyses suggested this was neither a lung adenocarcinoma nor NTL tissue. Probes targeting the $\mathrm{X}$ and $\mathrm{Y}$ chromosomes were excluded, as were probes containing a known single-nucleotide polymorphism, probes that contain repeat sequences of $\geq 10 \mathrm{bp}$, and probes that were found to be non-unique in the genome (Noushmehr et al. 2010). Hierarchical clustering was performed using Ward linkage with Euclidean distance for samples and Pearson correlation coefficients for probes. For each comparison analysis, the top 5000 most variable probes across all samples included in the comparison as measured

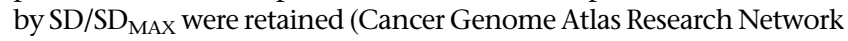
2011). Locus-by-locus analyses were conducted using the nonparametric Wilcoxon rank-sum test, and multiple comparisons correction was performed using $Q$-values from the qvalue package in R (Storey and Tibshirani 2003). Probes were considered statistically significantly different between the tested groups with a $Q<$ 0.05 . We also included an additional filter requiring the median $\beta$-value difference between groups to be $\geq 0.2$, or a minimum $20 \%$ difference for all group comparisons. MethyLight data were analyzed using Wilcoxon signed-rank tests on GraphPad Prism version 5.00 (GraphPad Software).

\section{Functional classification/gene network analyses}

Differentially methylated genes were analyzed for Gene Ontology enrichments in comparison to all genes available on the Illumina Infinium HumanMethylation27 platform using the DAVID Functional Annotation Tool (Huang da et al. 2009). Genes for which expression levels change in concordance with DNA methylation changes were analyzed for gene network and biological processes enrichment using IPA (Ingenuity Systems; http://www.ingenuity. com). Meta-analyses to identify correlated biosets and overlapping genes in publicly available data sets were performed using the NextBio online database (NextBio, Cupertino, CA; http://www. nextbio.com). Accession numbers are GSE10799, GSE17648, GSE19188, GSE19804, and GSE25062.

\section{Integration of gene expression analysis}

Gene expression profiles were generated using RNA obtained by TRIzol extraction (Invitrogen) from microdissected alternate sections of the same $59 \mathrm{EDRN}$ lung AD/NTL frozen tissue pairs used for the DNA methylation analysis. Expression data were obtained using the Illumina Human WG-6 v3.0 Expression BeadChips (Illumina) at the Genomics Core at UT Southwestern. Bead-summarized data were obtained using the Illumina BeadStudio software, expression values were $\log _{2}$-transformed, and Robust Spline Normalization (RSN) was performed with the lumi package in $\mathrm{R}(\mathrm{Du}$ et al. 2008). The ReMOAT annotation of gene expression data was used to include only "perfect" and "good" annotated probes (Barbosa-Morais et al. 2010). Exploratory quality-control analyses revealed no strong batch effects (data not shown), although one tumor sample was excluded (3035_T) due to quality concerns. Out of 766 differentially methylated genes identified $(Q<0.05$, median $\beta$-value difference $\geq 0.2$ ), we were able to examine gene expression levels for 709 genes after the probe quality filtering detailed above. For genes with multiple probes, we selected the probe with the highest variance and analyzed differential expression using $t$-tests and a Benjamini-Hochberg (BH) multiple comparisons correction. Statistical significance was called at BH-adjusted $p<0.05$. An additional stringent filter of mean twofold change was used to identify top changing genes. Correlation between gene expression and DNA methylation for each gene was measured using the Spearman correlation coefficient. For genes with multiple probes measuring DNA methylation, we selected the probe with the highest $\mathrm{SD} / \mathrm{SD}_{\max }$ value for DNA methylation.

\section{Data access}

The DNA methylation and expression data generated for the study have been submitted to the NCBI Gene Expression Omnibus (GEO) (http://www.ncbi.nlm.nih.gov/geo/) under accession number GSE32867. All genome-scale data generated in the study are also publicly available at the EDRN Public Portal (http://edrn.nci.nih. gov/).

\section{Acknowledgments}

This work was supported by the Canary and Labrecque Foundations in partnership with the Early Detection Research Network (EDRN) of the National Cancer Institute/National Institutes of Health (U01 CA086402), with additional support from NIH/NCI grants R01 CA119029 and CA120869 to I.A.L.O., and the Norris 
Comprehensive Cancer Center core grant NCI CCSG 5P30 CA014089. We thank all of the members of the Canary/EDRN lung team for fruitful discussions; members of the Laird-Offringa laboratory for helpful criticism; Crystal Marconett for comments on the manuscript; Jessica Nishiguchi for manuscript comments and help researching the aberrantly methylated genes; Daniel Weisenberger from the USC Epigenome Center for help with sample processing; and Toshinori Hinoue, Tim Triche Jr., Houtan Noushmehr, and Hui Shen for data analysis advice.

\section{References}

Acosta D, Suzuki M, Connolly D, Thompson RF, Fazzari MJ, Greally JM, Montagna C. 2011. DNA methylation changes in murine breast adenocarcinomas allow the identification of candidate genes for human breast carcinogenesis. Mamm Genome 22: 249-259.

Agarwal R, Mori Y, Cheng Y, Jin Z, Olaru AV, Hamilton JP, David S, Selaru FM, Yang J, Abraham JM, et al. 2009. Silencing of claudin-11 is associated with increased invasiveness of gastric cancer cells. PLoS ONE 4: e8002. doi: 10.1371/journal.pone.0008002.

Ahrendt SA, Decker PA, Alawi EA, Zhu YR, Sanchez-Cespedes M, Yang SC, Haasler GB, Kajdacsy-Balla A, Demeure MJ, Sidransky D. 2001. Cigarette smoking is strongly associated with mutation of the K-ras gene in patients with primary adenocarcinoma of the lung. Cancer 92: 15251530.

Andersson A, Srivastava MK, Harris-White M, Huang M, Zhu L, Elashoff D, Strieter RM, Dubinett SM, Sharma S. 2011. Role of CXCR3 ligands in IL7/IL-7R $\alpha$-Fc-mediated antitumor activity in lung cancer. Clin Cancer Res 17: $3660-3672$.

Barbosa-Morais NL, Dunning MJ, Samarajiwa SA, Darot JF, Ritchie ME, Lynch AG, Tavare S. 2010. A re-annotation pipeline for Illumina BeadArrays: Improving the interpretation of gene expression data. Nucleic Acids Res 38: e17. doi: 10.1093/nar/gkp942.

Beer DG, Kardia SL, Huang CC, Giordano TJ, Levin AM, Misek DE, Lin L, Chen G, Gharib TG, Thomas DG, et al. 2002. Gene-expression profiles predict survival of patients with lung adenocarcinoma. Nat Med 8: 816-824.

Belinsky SA. 2004. Gene-promoter hypermethylation as a biomarker in lung cancer. Nat Rev Cancer 4: 707-717.

Belinsky SA, Palmisano WA, Gilliland FD, Crooks LA, Divine KK, Winters SA, Grimes MJ, Harms HJ, Tellez CS, Smith TM, et al. 2002. Aberrant promoter methylation in bronchial epithelium and sputum from current and former smokers. Cancer Res 62: 2370-2377.

Bendik I, Schraml P, Lludwig CU. 1998. Characterization of MAST9/Hevin, a SPARC-like protein, that is down-regulated in non-small cell lung cancer. Cancer Res 58: 626-629.

Berman BP, Weisenberger DJ, Aman JF, Hinoue T, Ramjan Z, Liu Y, Noushmehr H, Lange CP, van Dijk CM, Tollenaar RA, et al. 2012. Regions of focal DNA hypermethylation and long-range hypomethylation in colorectal cancer coincide with nuclear lamina-associated domains. Nat Genet 44: $40-46$.

Bhattacharjee A, Richards WG, Staunton J, Li C, Monti S, Vasa P, Ladd C, Beheshti J, Bueno R, Gillette M, et al. 2001. Classification of human lung carcinomas by mRNA expression profiling reveals distinct adenocarcinoma subclasses. Proc Natl Acad Sci 98: 13790-13795.

Boldin MP, Goncharov TM, Goltsev YV, Wallach D. 1996. Involvement of $\mathrm{MACH}$, a novel MORT1/FADD-interacting protease, in Fas/APO-1- and TNF receptor-induced cell death. Cell 85: 803-815.

Breitling LP, Yang R, Korn B, Burwinkel B, Brenner H. 2011. Tobaccosmoking-related differential DNA methylation: $27 \mathrm{~K}$ discovery and replication. Am J Hum Genet 88: 450-457.

Brenet F, Moh M, Funk P, Feierstein E, Viale AJ, Socci ND, Scandura JM. 2011. DNA methylation of the first exon is tightly linked to transcriptional silencing. PLOS ONE 6: e14524. doi: 10.1371/journal.pone.0014524.

Brock MV, Hooker CM, Ota-Machida E, Han Y, Guo M, Ames S, Glockner S, Piantadosi S, Gabrielson E, Pridham G, et al. 2008. DNA methylation markers and early recurrence in stage I lung cancer. N Engl J Med 358: 1118-1128.

Campan M, Weisenberger DJ, Trinh B, Laird PW. 2009. MethyLight. Methods Mol Biol 507: 325-337.

Cancer Genome Atlas Research Network. 2011. Integrated genomic analyses of ovarian carcinoma. Nature 474: 609-615.

Cheong N, Zhang H, Madesh M, Zhao M, Yu K, Dodia C, Fisher AB, Savani RC, Shuman H. 2007. ABCA3 is critical for lamellar body biogenesis in vivo. J Biol Chem 282: 23811-23817.

Chioni AM, Brackenbury WJ, Calhoun JD, Isom LL, Djamgoz MB. 2009. A novel adhesion molecule in human breast cancer cells: Voltage-gated $\mathrm{Na}^{+}$channel $\beta 1$ subunit. Int J Biochem Cell Biol 41: 1216-1227.
Christensen BC, Marsit CJ, Houseman EA, Godleski JJ, Longacker JL, Zheng S, Yeh RF, Wrensch MR, Wiemels JL, Karagas MR, et al. 2009. Differentiation of lung adenocarcinoma, pleural mesothelioma, and nonmalignant pulmonary tissues using DNA methylation profiles. Cancer Res 69: 6315-6321.

Clark SJ. 2007. Action at a distance: Epigenetic silencing of large chromosomal regions in carcinogenesis. Hum Mol Genet 16: R88R95.

Clausen KA, Blish KR, Birse CE, Triplette MA, Kute TE, Russell GB, D'Agostino RB Jr, Miller LD, Torti FM, Torti SV. 2011. SOSTDC1 differentially modulates Smad and $\beta$-catenin activation and is downregulated in breast cancer. Breast Cancer Res Treat 129: 737-746.

Dietrich D, Krispin M, Dietrich J, Fassbender A, Lewin J, Harbeck N, Schmitt M, Eppenberger-Castori S, Vuaroqueaux V, Spyratos F, et al. 2010. CDO1 promoter methylation is a biomarker for outcome prediction of anthracycline treated, estrogen receptor-positive, lymph node-positive breast cancer patients. BMC Cancer 10: 247.

Divine KK, Pulling LC, Marron-Terada PG, Liechty KC, Kang T, Schwartz AG, Bocklage TJ, Coons TA, Gilliland FD, Belinsky SA. 2005. Multiplicity of abnormal promoter methylation in lung adenocarcinomas from smokers and never smokers. Int I Cancer 114: 400-405.

Dranoff G. 2004. Cytokines in cancer pathogenesis and cancer therapy. Nat Rev Cancer 4: 11-22.

Du P, Kibbe WA, Lin SM. 2008. lumi: A pipeline for processing Illumina microarray. Bioinformatics 24: 1547-1548.

Esteller M. 2003. Relevance of DNA methylation in the management of cancer. Lancet Oncol 4: 351-358.

Esteller M, Sanchez-Cespedes M, Rosell R, Sidransky D, Baylin SB, Herman JG. 1999. Detection of aberrant promoter hypermethylation of tumor suppressor genes in serum DNA from non-small cell lung cancer patients. Cancer Res 59: 67-70.

Fu DY, Wang ZM, Li C, Wang BL, Shen ZZ, Huang W, Shao ZM. 2010. Sox17, the canonical Wnt antagonist, is epigenetically inactivated by promoter methylation in human breast cancer. Breast Cancer Res Treat 119: 601612.

Galm O, Yoshikawa H, Esteller M, Osieka R, Herman JG. 2003. SOCS-1, a negative regulator of cytokine signaling, is frequently silenced by methylation in multiple myeloma. Blood 101: 2784-2788.

Gentleman RC, Carey VJ, Bates DM, Bolstad B, Dettling M, Dudoit S, Ellis B, Gautier L, Ge Y, Gentry J, et al. 2004. Bioconductor: Open software development for computational biology and bioinformatics. Genome Biol 5: R80.

Ghadersohi A, Odunsi K, Lele S, Collins Y, Greco WR, Winston J, Liang P, Sood AK. 2004. Prostate derived Ets transcription factor shows better tumor-association than other cancer-associated molecules. Oncol Rep 11: $453-458$.

Goldenring JR, Nam KT. 2011. Rab25 as a tumour suppressor in colon carcinogenesis. Br J Cancer 104: 33-36.

Goto Y, Shinjo K, Kondo Y, Shen L, Toyota M, Suzuki H, Gao W, An B, Fujii M, Murakami H, et al. 2009. Epigenetic profiles distinguish malignant pleural mesothelioma from lung adenocarcinoma. Cancer Res 69: 90739082.

Han H, Cortez CC, Yang X, Nichols PW, Jones PA, Liang G. 2011. DNA methylation directly silences genes with non-CpG island promoters and establishes a nucleosome occupied promoter. Hum Mol Genet 20: 42994310.

Hinoue T, Weisenberger DJ, Lange CP, Shen H, Byun HM, Van Den Berg D, Malik S, Pan F, Noushmehr H, van Dijk CM, et al. 2012. Genome-scale analysis of aberrant DNA methylation in colorectal cancer. Genome Res 22: $271-282$.

Hiraoka N, Yamazaki-Itoh R, Ino Y, Mizuguchi Y, Yamada T, Hirohashi S, Kanai Y. 2011. CXCL17 and ICAM2 are associated with a potential antitumor immune response in early intraepithelial stages of human pancreatic carcinogenesis. Gastroenterology 140: 310-321.

Hou J, Aerts J, den Hamer B, van Ijcken W, den Bakker M, Riegman P, van der Leest C, van der Spek P, Foekens JA, Hoogsteden HC, et al. 2010. Gene expression-based classification of non-small cell lung carcinomas and survival prediction. PLoS ONE 5: e10312. doi: 10.1371/journal. pone.0010312.

Huang da W, Sherman BT, Lempicki RA. 2009. Systematic and integrative analysis of large gene lists using DAVID bioinformatics resources. Nat Protoc 4: 44-57.

Huang J, Zheng DL, Qin FS, Cheng N, Chen H, Wan BB, Wang YP, Xiao HS, Han ZG. 2010. Genetic and epigenetic silencing of SCARA5 may contribute to human hepatocellular carcinoma by activating FAK signaling. J Clin Invest 120: 223-241.

Hu-Lowe DD, Chen E, Zhang L, Watson KD, Mancuso P, Lappin P, Wickman G, Chen JH, Wang J, Jiang X, et al. 2011. Targeting activin receptor-like kinase 1 inhibits angiogenesis and tumorigenesis through a mechanism of action complementary to anti-VEGF therapies. Cancer Res 71: 13621373

\section{Genome Research}

www.genome.org 
Hussain M, Rao M, Humphries AE, Hong JA, Liu F, Yang M, Caragacianu D, Schrump DS. 2009. Tobacco smoke induces Polycomb-mediated repression of Dickkopf-1 in lung cancer cells. Cancer Res 69: 35703578.

Ibragimova I, Ibanez de Caceres I, Hoffman AM, Potapova A, Dulaimi E, AlSaleem T, Hudes GR, Ochs MF, Cairns P. 2010. Global reactivation of epigenetically silenced genes in prostate cancer. Cancer Prev Res (Phila) 3: 1084-1092.

Irizarry RA, Ladd-Acosta C, Wen B, Wu Z, Montano C, Onyango P, Cui H, Gabo K, Rongione M, Webster M, et al. 2009. The human colon cancer methylome shows similar hypo- and hypermethylation at conserved tissue-specific CpG island shores. Nat Genet 41: 178-186.

Issa JP. 2004. CpG island methylator phenotype in cancer. Nat Rev Cancer 4: 988-993.

Jemal A, Bray F, Center MM, Ferlay J, Ward E, Forman D. 2011. Global cancer statistics. CA Cancer J Clin 61: 69-90.

Jensen TJ, Novak P, Eblin KE, Gandolfi AJ, Futscher BW. 2008. Epigenetic remodeling during arsenical-induced malignant transformation. Carcinogenesis 29: 1500-1508.

Jones PA. 2002. DNA methylation and cancer. Oncogene 21: 5358-5360.

Ju YS, Lee WC, Shin JY, Lee S, Bleazard T, Won JK, Kim YT, Kim JI, Kang JH, Seo JS. 2012. A transforming KIF5B and RET gene fusion in lung adenocarcinoma revealed from whole-genome and transcriptome sequencing. Genome Res 22: 436-445.

Kaur S, Leszczynska K, Abraham S, Scarcia M, Hiltbrunner S, Marshall CJ, Mavria G, Bicknell R, Heath VL. 2011. RhoJ/TCL regulates endothelial motility and tube formation and modulates actomyosin contractility and focal adhesion numbers. Arterioscler Thromb Vasc Biol 31: 657664.

Kerr KM, Galler JS, Hagen JA, Laird PW, Laird-Offringa IA. 2007. The role of DNA methylation in the development and progression of lung adenocarcinoma. Dis Markers 23: 5-30.

Kikuchi S, Yamada D, Fukami T, Masuda M, Sakurai-Yageta M, Williams YN, Maruyama T, Asamura H, Matsuno Y, Onizuka M, et al. 2005. Promoter methylation of DAL-1/4.1B predicts poor prognosis in non-small cell lung cancer. Clin Cancer Res 11: 2954-2961.

Kim H, Lapointe J, Kaygusuz G, Ong DE, Li C, van de Rijn M, Brooks JD, Pollack JR. 2005. The retinoic acid synthesis gene ALDH1a2 is a candidate tumor suppressor in prostate cancer. Cancer Res 65: 81188124 .

Kobayashi K, Nishioka M, Kohno T, Nakamoto M, Maeshima A, Aoyagi K, Sasaki H, Takenoshita S, Sugimura H, Yokota J. 2004. Identification of genes whose expression is upregulated in lung adenocarcinoma cells in comparison with type II alveolar cells and bronchiolar epithelial cells in vivo. Oncogene 23: 3089-3096.

Kohda M, Hoshiya H, Katoh M, Tanaka I, Masuda R, Takemura T, Fujiwara M, Oshimura M. 2001. Frequent loss of imprinting of IGF2 and MEST in lung adenocarcinoma. Mol Carcinog 31: 184-191.

Kubo T, Yamamoto H, Ichimura K, Jida M, Hayashi T, Otani H, Tsukuda K, Sano Y, Kiura K, Toyooka S. 2009. DNA methylation in small lung adenocarcinoma with bronchioloalveolar carcinoma components. Lung Cancer 65: 328-332.

Kupershmidt I, Su OJ, Grewal A, Sundaresh S, Halperin I, Flynn J, Shekar M, Wang H, Park J, Cui W, et al. 2010. Ontology-based meta-analysis of global collections of high-throughput public data. PLOS ONE 5: e13066. doi: 10.1371/journal.pone.0013066.

Landi MT, Dracheva T, Rotunno M, Figueroa JD, Liu H, Dasgupta A, Mann FE, Fukuoka J, Hames M, Bergen AW, et al. 2008. Gene expression signature of cigarette smoking and its role in lung adenocarcinoma development and survival. PLoS One 3: e1651. doi: 10.1371/journal. pone.0001651.

Larsen JE, Pavey SJ, Passmore LH, Bowman RV, Hayward NK, Fong KM. 2007. Gene expression signature predicts recurrence in lung adenocarcinoma. Clin Cancer Res 13: 2946-2954.

Leandro-Garcia LJ, Leskela S, Landa I, Montero-Conde C, Lopez-Jimenez E, Leton R, Cascon A, Robledo M, Rodriguez-Antona C. 2010. Tumoral and tissue-specific expression of the major human $\beta$-tubulin isotypes. Cytoskeleton (Hoboken) 67: 214-223.

LeekJT, Scharpf RB, Bravo HC, Simcha D, Langmead B, Johnson WE, Geman D, Baggerly K, Irizarry RA. 2010. Tackling the widespread and critical impact of batch effects in high-throughput data. Nat Rev Genet 11: 733-739

Lehtonen ST, Svensk AM, Soini Y, Paakko P, Hirvikoski P, Kang SW, Saily M, Kinnula VL. 2004. Peroxiredoxins, a novel protein family in lung cancer. Int J Cancer 111: 514-521.

Lemjabbar-Alaoui H, Dasari V, Sidhu SS, Mengistab A, Finkbeiner W, Gallup M, Basbaum C. 2006. Wnt and Hedgehog are critical mediators of cigarette smoke-induced lung cancer. PLOS ONE 1: e93. doi: 10.1371/ journal.pone.0000093.

Leppanen VM, Bespalov MM, Runeberg-Roos P, Puurand U, Merits A, Saarma M, Goldman A. 2004. The structure of GFR $\alpha 1$ domain 3 reveals new insights into GDNF binding and RET activation. EMBO $J$ 23: 1452-1462.

Li Y, Dong X, Yin Y, Su Y, Xu Q, Zhang Y, Pang X, Chen W. 2005. BJ-TSA-9, a novel human tumor-specific gene, has potential as a biomarker of lung cancer. Neoplasia 7: 1073-1080.

Li L, Lee KM, Han W, Choi JY, Lee JY, Kang GH, Park SK, Noh DY, Yoo KY, Kang D. 2010. Estrogen and progesterone receptor status affect genomewide DNA methylation profile in breast cancer. Hum Mol Genet 19: 4273-4277.

Li N, Grivennikov SI, Karin M. 2011. The unholy trinity: Inflammation, cytokines, and STAT3 shape the cancer microenvironment. Cancer Cell 19: 429-431.

Lind GE, Ahlquist T, Lothe RA. 2007. DNA hypermethylation of MAL: A promising diagnostic biomarker for colorectal tumors. Gastroenterology 132: $1631-1632$

Lipson D, Capelletti M, Yelensky R, Otto G, Parker A, Jarosz M, Curran JA, Balasubramanian S, Bloom T, Brennan KW, et al. 2012. Identification of new ALK and RET gene fusions from colorectal and lung cancer biopsies. Nat Med 18: 382-384.

Liu L, Liao GQ, He P, Zhu H, Liu PH, Qu YM, Song XM, Xu QW, Gao Q, Zhang Y, et al. 2008. Detection of circulating cancer cells in lung cancer patients with a panel of marker genes. Biochem Biophys Res Commun 372: 756-760

Lopez-Serra P, Esteller M. 2012. DNA methylation-associated silencing of tumor-suppressor microRNAs in cancer. Oncogene 31: 1609-1622.

Lu TP, Tsai MH, Lee JM, Hsu CP, Chen PC, Lin CW, Shih JY, Yang PC, Hsiao CK, Lai LC, et al. 2010. Identification of a novel biomarker, SEMA5A, for non-small cell lung carcinoma in nonsmoking women. Cancer Epidemiol Biomarkers Prev 19: 2590-2597.

Marsit CJ, Houseman EA, Christensen BC, Eddy K, Bueno R, Sugarbaker DJ, Nelson HH, Karagas MR, Kelsey KT. 2006. Examination of a CpG island methylator phenotype and implications of methylation profiles in solid tumors. Cancer Res 66: 10621-10629.

Maunakea AK, Nagarajan RP, Bilenky M, Ballinger TJ, D'Souza C, Fouse SD Johnson BE, Hong C, Nielsen C, Zhao Y, et al. 2010. Conserved role of intragenic DNA methylation in regulating alternative promoters. Nature 466: 253-257.

Mazieres J, He B, You L, Xu Z, Jablons DM. 2005. Wnt signaling in lung cancer. Cancer Lett 222: 1-10.

Mazzieri R, Pucci F, Moi D, Zonari E, Ranghetti A, Berti A, Politi LS, Gentner B, Brown JL, Naldini L, et al. 2011. Targeting the ANG2/TIE2 axis inhibits tumor growth and metastasis by impairing angiogenesis and disabling rebounds of proangiogenic myeloid cells. Cancer Cell 19: 512-526.

Mura M, Swain RK, Zhuang X, Vorschmitt H, Reynolds G, Durant S, Beesley JF, Herbert JM, Sheldon H, Andre M, et al. 2012. Identification and angiogenic role of the novel tumor endothelial marker CLEC14A. Oncogene 31: 293-305.

Nguyen DX, Chiang AC, Zhang XH, Kim JY, Kris MG, Ladanyi M, Gerald WL, Massague J. 2009. WNT/TCF signaling through LEF1 and HOXB9 mediates lung adenocarcinoma metastasis. Cell 138: 51-62.

Nishihara H, Maeda M, Oda A, Tsuda M, Sawa H, Nagashima K, Tanaka S. 2002. DOCK2 associates with CrkL and regulates Rac1 in human leukemia cell lines. Blood 100: 3968-3974.

Niwa Y, Kanda H, Shikauchi Y, Saiura A, Matsubara K, Kitagawa T, Yamamoto J, Kubo T, Yoshikawa H. 2005. Methylation silencing of SOCS-3 promotes cell growth and migration by enhancing JAK/STAT and FAK signalings in human hepatocellular carcinoma. Oncogene 24: 64066417.

Noordhuis MG, Fehrmann RS, Wisman GB, Nijhuis ER, van Zanden JJ, Moerland PD, Ver Loren van Themaat E, Volders HH, Kok M, ten Hoor $\mathrm{KA}$, et al. 2011. Involvement of the TGF- $\beta$ and $\beta$-catenin pathways in pelvic lymph node metastasis in early-stage cervical cancer. Clin Cancer Res 17: 1317-1330.

Noushmehr H, Weisenberger DJ, Diefes K, Phillips HS, Pujara K, Berman BP, Pan F, Pelloski CE, Sulman EP, Bhat KP, et al. 2010. Identification of a CPG island methylator phenotype that defines a distinct subgroup of glioma. Cancer Cell 17: 510-522.

Ogino S, Kawasaki T, Kirkner GJ, Loda M, Fuchs CS. 2006. CpG island methylator phenotype-low (CIMP-low) in colorectal cancer: Possible associations with male sex and KRAS mutations. J Mol Diagn 8: 582588.

Ohm JE, McGarvey KM, Yu X, Cheng L, Schuebel KE, Cope L, Mohammad HP, Chen W, Daniel VC, Yu W, et al. 2007. A stem cell-like chromatin pattern may predispose tumor suppressor genes to DNA hypermethylation and heritable silencing. Nat Genet 39: 237-242.

Oka R, Sasagawa T, Ninomiya I, Miwa K, Tanii H, Saijoh K. 2001. Reduction in the local expression of complement component 6 (C6) and 7 (C7) mRNAs in oesophageal carcinoma. Eur J Cancer 37: 1158-1165.

Osada H, Tatematsu Y, Yatabe Y, Nakagawa T, Konishi H, Harano T, Tezel E, Takada M, Takahashi T. 2002. Frequent and histological type-specific 
inactivation of 14-3-3 $\sigma$ in human lung cancers. Oncogene 21: 24182424 .

Oster B, Thorsen K, Lamy P, Wojdacz TK, Hansen LL, BirkenkampDemtroder K, Sorensen KD, Laurberg S, Orntoft TF, Andersen CL. 2011. Identification and validation of highly frequent $\mathrm{CpG}$ island hypermethylation in colorectal adenomas and carcinomas. Int J Cancer 129: $2855-2866$.

Pao W, Girard N. 2011. New driver mutations in non-small-cell lung cancer. Lancet Oncol 12: 175-180.

Pao W, Miller V, Zakowski M, Doherty J, Politi K, Sarkaria I, Singh B, Heelan R, Rusch V, Fulton L, et al. 2004. EGF receptor gene mutations are common in lung cancers from "never smokers" and are associated with sensitivity of tumors to gefitinib and erlotinib. Proc Natl Acad Sci 101: 13306-13311.

Pao W, Miller VA, Politi KA, Riely GJ, Somwar R, Zakowski MF, Kris MG, Varmus H. 2005a. Acquired resistance of lung adenocarcinomas to gefitinib or erlotinib is associated with a second mutation in the EGFR kinase domain. PLoS Med 2: e73. doi: 10.1371/journal.pmed. 0020073.

Pao W, Wang TY, Riely GJ, Miller VA, Pan Q, Ladanyi M, Zakowski MF, Heelan RT, Kris MG, Varmus HE. 2005b. KRAS mutations and primary resistance of lung adenocarcinomas to gefitinib or erlotinib. PLoS Med 2: e17. doi: 10.1371/journal.pmed.0020017.

Park K, Chung YJ, So H, Kim K, Park J, Oh M, Jo M, Choi K, Lee EJ, Choi YL, et al. 2011. AGR2, a mucinous ovarian cancer marker, promotes cell proliferation and migration. Exp Mol Med 43: 91-100.

Pedersen KS, Bamlet WR, Oberg AL, de Andrade M, Matsumoto ME, Tang $\mathrm{H}$ Thibodeau SN, Petersen GM, Wang L. 2011. Leukocyte DNA methylation signature differentiates pancreatic cancer patients from healthy controls. PLOS ONE 6: e18223. doi: 10.1371/journal.pone.0018223.

Piepoli A, Cotugno R, Merla G, Gentile A, Augello B, Quitadamo M, Merla A, Panza A, Carella M, Maglietta R, et al. 2009. Promoter methylation correlates with reduced NDRG2 expression in advanced colon tumour. BMC Med Genomics 2: 11. doi: 10.1186/1755-8794-2-11.

Pizzi M, Fassan M, Balistreri M, Galligioni A, Rea F, Rugge M. 2012. Anterior gradient 2 overexpression in lung adenocarcinoma. Appl Immunohistochem Mol Morphol 20: 31-36.

Pulling LC, Divine KK, Klinge DM, Gilliland FD, Kang T, Schwartz AG, Bocklage TJ, Belinsky SA. 2003. Promoter hypermethylation of the $O^{6}$-methylguanine-DNA methyltransferase gene: More common in lung adenocarcinomas from never-smokers than smokers and associated with tumor progression. Cancer Res 63: 4842-4848.

Pyle-Chenault RA, Stolk JA, Molesh DA, Boyle-Harlan D, McNeill PD, Repasky EA, Jiang Z, Fanger GR, Xu J. 2005. VSGP/F-spondin: A new ovarian cancer marker. Tumour Biol 26: 245-257.

R Development Core Team. 2011. R: A language and environment for statistical computing. R Foundation for Statistical Computing, Vienna, Austria. http://www.R-project.org/.

Ramachandran V, Arumugam T, Wang H, Logsdon CD. 2008. Anterior gradient 2 is expressed and secreted during the development of pancreatic cancer and promotes cancer cell survival. Cancer Res 68: 7811-7818

Rauch T, Wang Z, Zhang X, Zhong X, Wu X, Lau SK, Kernstine KH, Riggs AD, Pfeifer GP. 2007. Homeobox gene methylation in lung cancer studied by genome-wide analysis with a microarray-based methylated CpG island recovery assay. Proc Natl Acad Sci 104: 5527-5532.

Remmelink M, Mijatovic T, Gustin A, Mathieu A, Rombaut K, Kiss R, Salmon I, Decaestecker C. 2005. Identification by means of cDNA microarray analyses of gene expression modifications in squamous non-small cell lung cancers as compared to normal bronchial epithelial tissue. Int J Oncol 26: 247-258.

Risch A, Plass C. 2008. Lung cancer epigenetics and genetics. Int J Cancer 123: $1-7$.

Rodenhiser DI, Andrews J, Kennette W, Sadikovic B, Mendlowitz A, Tuck AB, Chambers AF. 2008. Epigenetic mapping and functional analysis in a breast cancer metastasis model using whole-genome promoter tiling microarrays. Breast Cancer Res 10: R62. doi: 10.1186/bcr2121.

Rodriguez-Paredes M, Esteller M. 2011. Cancer epigenetics reaches mainstream oncology. Nat Med 17: 330-339.

Rohan S, Tu JJ, Kao J, Mukherjee P, Campagne F, Zhou XK, Hyjek E, Alonso MA, Chen YT. 2006. Gene expression profiling separates chromophobe renal cell carcinoma from oncocytoma and identifies vesicular transport and cell junction proteins as differentially expressed genes. Clin Cancer Res 12: 6937-6945.

Rui X, Tsao J, Scheys JO, Hammer GD, Schimmer BP. 2008. Contributions of specificity protein-1 and steroidogenic factor 1 to Adcy 4 expression in Y1 mouse adrenal cells. Endocrinology 149: 3668-3678.

Sakakura C, Hasegawa K, Miyagawa K, Nakashima S, Yoshikawa T, Kin S, Nakase Y, Yazumi S, Yamagishi H, Okanoue T, et al. 2005. Possible involvement of RUNX3 silencing in the peritoneal metastases of gastric cancers. Clin Cancer Res 11: 6479-6488.
Sakhinia E, Farahangpour M, Tholouli E, Liu Yin JA, Hoyland JA, Byers RJ. 2006. Comparison of gene-expression profiles in parallel bone marrow and peripheral blood samples in acute myeloid leukaemia by real-time polymerase chain reaction. J Clin Pathol 59: 1059-1065.

Sakthianandeswaren A, Christie M, D'Andreti C, Tsui C, Jorissen RN, Li S, Fleming NI, Gibbs P, Lipton L, Malaterre J, et al. 2011. PHLDA1 expression marks the putative epithelial stem cells and contributes to intestinal tumorigenesis. Cancer Res 71: 3709-3719.

Sartor MA, Dolinoy DC, Jones TR, Colacino JA, Prince ME, Carey TE, Rozek LS. 2011. Genome-wide methylation and expression differences in $\mathrm{HPV}^{+}$and $\mathrm{HPV}^{-}$squamous cell carcinoma cell lines are consistent with divergent mechanisms of carcinogenesis. Epigenetics 6: 777-787.

Satelli A, Rao PS, Thirumala S, Rao US. 2011. Galectin-4 functions as a tumor suppressor of human colorectal cancer. Int J Cancer 129: 799-809.

Sathyanarayana UG, Toyooka S, Padar A, Takahashi T, Brambilla E, Minna JD, Gazdar AF. 2003. Epigenetic inactivation of laminin-5-encoding genes in lung cancers. Clin Cancer Res 9: 2665-2672.

Sato M, Mori Y, Sakurada A, Fujimura S, Horii A. 1998. The H-cadherin (CDH13) gene is inactivated in human lung cancer. Hum Genet 103: 96-101.

Sato N, Fukushima N, Maitra A, Matsubayashi H, Yeo CJ, Cameron JL, Hruban RH, Goggins M. 2003. Discovery of novel targets for aberrant methylation in pancreatic carcinoma using high-throughput microarrays. Cancer Res 63: 3735-3742.

Schimanski S, Wild PJ, Treeck O, Horn F, Sigruener A, Rudolph C, Blaszyk H, Klinkhammer-Schalke M, Ortmann O, Hartmann A, et al. 2010. Expression of the lipid transporters ABCA3 and ABCA1 is diminished in human breast cancer tissue. Horm Metab Res 42: 102-109.

Schlesinger Y, Straussman R, Keshet I, Farkash S, Hecht M, Zimmerman J, Eden E, Yakhini Z, Ben-Shushan E, Reubinoff BE, et al. 2007. Polycombmediated methylation on Lys27 of histone H3 pre-marks genes for de novo methylation in cancer. Nat Genet 39: 232-236.

Selamat SA, Galler JS, Joshi AD, Fyfe MN, Campan M, Siegmund KD, Kerr KM, Laird-Offringa IA. 2011. DNA methylation changes in atypical adenomatous hyperplasia, adenocarcinoma in situ, and lung adenocarcinoma. PLOS ONE 6: e21443. doi: 10.1371/journal.pone. 0021443.

Shen L, Toyota M, Kondo Y, Lin E, Zhang L, Guo Y, Hernandez NS, Chen X, Ahmed S, Konishi K, et al. 2007. Integrated genetic and epigenetic analysis identifies three different subclasses of colon cancer. Proc Natl Acad Sci 104: 18654-18659.

Shiba-Ishii A, Kano J, Morishita Y, Sato Y, Minami Y, Noguchi M. 2011. High expression of stratifin is a universal abnormality during the course of malignant progression of early-stage lung adenocarcinoma. Int J Cancer 129: $2445-2453$.

Shimizu H, Horii A, Sunamura M, Motoi F, Egawa S, Unno M, Fukushige S. 2011. Identification of epigenetically silenced genes in human pancreatic cancer by a novel method "microarray coupled with methylCpG targeted transcriptional activation" (MeTA-array). Biochem Biophys Res Commun 411: 162-167.

Shiraishi M, Sekiguchi A, Oates AJ, Terry MJ, Miyamoto Y. 2002. HOX gene clusters are hotspots of de novo methylation in CpG islands of human lung adenocarcinomas. Oncogene 21: 3659-3662.

Shulenin S, Nogee LM, Annilo T, Wert SE, Whitsett JA, Dean M. 2004. $A B C A 3$ gene mutations in newborns with fatal surfactant deficiency. N Engl J Med 350: 1296-1303.

Storey JD, Tibshirani R. 2003. Statistical significance for genomewide studies. Proc Natl Acad Sci 100: 9440-9445.

Sun S, Schiller JH, Gazdar AF. 2007. Lung cancer in never smokers-a different disease. Nat Rev Cancer 7: 778-790.

Sunaga N, Imai H, Shimizu K, Shames DS, Kakegawa S, Girard L, Sato M, Kaira K, Ishizuka T, Gazdar AF, et al. 2012. Oncogenic KRAS-induced interleukin-8 overexpression promotes cell growth and migration and contributes to aggressive phenotypes of non-small cell lung cancer. Int J Cancer 130: 1733-1744.

Suzuki M, Shigematsu H, Iizasa T, Hiroshima K, Nakatani Y, Minna JD, Gazdar AF, Fujisawa T. 2006. Exclusive mutation in epidermal growth factor receptor gene, HER-2, and KRAS, and synchronous methylation of nonsmall cell lung cancer. Cancer 106: 2200-2207.

Suzuki-Ishigaki S, Numayama-Tsuruta K, Kuramasu A, Sakurai E, Makabe Y, Shimura S, Shirato K, Igarashi K, Watanabe T, Ohtsu H. 2000. The mouse L-histidine decarboxylase gene: Structure and transcriptional regulation by CpG methylation in the promoter region. Nucleic Acids Res 28: 26272633.

Tanaka S, Pero SC, Taguchi K, Shimada M, Mori M, Krag DN, Arii S. 2006. Specific peptide ligand for Grb7 signal transduction protein and pancreatic cancer metastasis. J Natl Cancer Inst 98: 491-498.

Tao R, Li J, Xin J, Wu J, Guo J, Zhang L, Jiang L, Zhang W, Yang Z, Li L. 2011. Methylation profile of single hepatocytes derived from hepatitis B virusrelated hepatocellular carcinoma. PLOS ONE 6: e19862. doi: 10.1371/ journal.pone.0019862.

\section{Genome Research}


Teodoridis JM, Hardie C, Brown R. 2008. CpG island methylator phenotype (CIMP) in cancer: Causes and implications. Cancer Lett 268: 177-186.

Tessema M, Belinsky SA. 2008. Mining the epigenome for methylated genes in lung cancer. Proc Am Thorac Soc 5: 806-810.

Toh CK, Gao F, Lim WT, Leong SS, Fong KW, Yap SP, Hsu AA, Eng P, Koong HN, Thirugnanam A, et al. 2006. Never-smokers with lung cancer: Epidemiologic evidence of a distinct disease entity. J Clin Oncol 24: 2245-2251.

Tommasi S, Kim SI, Zhong X, Wu X, Pfeifer GP, Besaratinia A. 2010. Investigating the epigenetic effects of a prototype smoke-derived carcinogen in human cells. PLoS ONE 5: e10594. doi: 10.1371/journal. pone.0010594

Toyooka S, Maruyama R, Toyooka KO, McLerran D, Feng Z, Fukuyama Y, Virmani AK, Zochbauer-Muller S, Tsukuda K, Sugio K, et al. 2003. Smoke exposure, histologic type and geography-related differences in the methylation profiles of non-small cell lung cancer. Int J Cancer 103: 153-160.

Toyooka S, Tokumo M, Shigematsu H, Matsuo K, Asano H, Tomii K, Ichihara S, Suzuki M, Aoe M, Date H, et al. 2006. Mutational and epigenetic evidence for independent pathways for lung adenocarcinomas arising in smokers and never smokers. Cancer Res 66: 1371-1375.

Toyoshima Y, Karas M, Yakar S, Dupont J, Lee H, LeRoith D. 2004. TDAG51 mediates the effects of insulin-like growth factor I (IGF-I) on cell survival. J Biol Chem 279: 25898-25904.

Toyota M, Ahuja N, Ohe-Toyota M, Herman JG, Baylin SB, Issa JP. 1999. CpG island methylator phenotype in colorectal cancer. Proc Natl Acad Sci 96: 8681-8686.

Travis WD, Brambilla E, Noguchi M, Nicholson AG, Geisinger KR, Yatabe Y, Beer DG, Powell CA, Riely GJ, Van Schil PE, et al. 2011. International Association for the Study of Lung Cancer/American Thoracic Society/ European Respiratory Society international multidisciplinary classification of lung adenocarcinoma. J Thorac Oncol 6: 244-285.

Tripodi D, Quemener S, Renaudin K, Ferron C, Malard O, Guisle-Marsollier I, Sebille-Rivain V, Verger C, Geraut C, Gratas-Rabbia-Re C. 2009. Gene expression profiling in sinonasal adenocarcinoma. BMC Med Genomics 2: 65 . doi: $10.1186 / 1755-8794-2-65$

Tsou JA, Shen LY, Siegmund KD, Long TI, Laird PW, Seneviratne CK, Koss MN, Pass HI, Hagen JA, Laird-Offringa IA. 2005. Distinct DNA methylation profiles in malignant mesothelioma, lung adenocarcinoma, and non-tumor lung. Lung Cancer 47: 193-204.

Tsou JA, Galler JS, Siegmund KD, Laird PW, Turla S, Cozen W, Hagen JA, Koss MN, Laird-Offringa IA. 2007. Identification of a panel of sensitive and specific DNA methylation markers for lung adenocarcinoma. Mol Cancer 6: 70.

Usadel H, Brabender J, Danenberg KD, Jeronimo C, Harden S, Engles J, Danenberg PV, Yang S, Sidransky D. 2002. Quantitative adenomatous polyposis coli promoter methylation analysis in tumor tissue, serum, and plasma DNA of patients with lung cancer. Cancer Res 62: 371-375.

Vaissiere T, Hung RJ, Zaridze D, Moukeria A, Cuenin C, Fasolo V, Ferro G, Paliwal A, Hainaut P, Brennan P, et al. 2009. Quantitative analysis of DNA methylation profiles in lung cancer identifies aberrant DNA methylation of specific genes and its association with gender and cancer risk factors. Cancer Res 69: 243-252.

van Vlodrop IJ, Niessen HE, Derks S, Baldewijns M, Van Criekinge W, Herman JG, van Engeland M. 2011. Analysis of promoter CpG island hypermethylation in cancer: Location, location, location! Clin Cancer Res 17: 4225-4231.

Vanderlaag KE, Hudak S, Bald L, Fayadat-Dilman L, Sathe M, Grein J, Janatpour MJ. 2010. Anterior gradient-2 plays a critical role in breast cancer cell growth and survival by modulating cyclin D1 estrogen receptor- $\alpha$ and survivin. Breast Cancer Res 12: R32. doi: $10.1186 / \mathrm{bcr} 2586$

Vitale L, Frabetti F, Huntsman SA, Canaider S, Casadei R, Lenzi L, Facchin F, Carinci P, Zannotti M, Coppola D, et al. 2007. Sequence, "subtle" alternative splicing and expression of the CYYR1 (cysteine/tyrosine-rich 1) mRNA in human neuroendocrine tumors. BMC Cancer 7: 66. doi: 10.1186/1471-2407-7-66.

Walker BA, Wardell CP, Chiecchio L, Smith EM, Boyd KD, Neri A, Davies FE, Ross FM, Morgan GJ. 2011. Aberrant global methylation patterns affect the molecular pathogenesis and prognosis of multiple myeloma. Blood 117: $553-562$.

Wang S, El-Deiry WS. 2003. TRAIL and apoptosis induction by TNF-family death receptors. Oncogene 22: 8628-8633.

Wang KK, Liu N, Radulovich N, Wigle DA, Johnston MR, Shepherd FA, Minden MD, Tsao MS. 2002. Novel candidate tumor marker genes for lung adenocarcinoma. Oncogene 21: 7598-7604.

Wang L, Aakre JA, Jiang R, Marks RS, Wu Y, Chen J, Thibodeau SN, Pankratz VS, Yang P. 2010. Methylation markers for small cell lung cancer in peripheral blood leukocyte DNA. J Thorac Oncol 5: 778-785.

Watanabe M, Takemasa I, Kaneko N, Yokoyama Y, Matsuo E, Iwasa S, Mori M, Matsuura N, Monden M, Nishimura O. 2011. Clinical significance of circulating galectins as colorectal cancer markers. Oncol Rep 25: 12171226.

Weisenberger DJ, Siegmund KD, Campan M, Young J, Long TI, Faasse MA, Kang GH, Widschwendter M, Weener D, Buchanan D, et al. 2006. CpG island methylator phenotype underlies sporadic microsatellite instability and is tightly associated with BRAF mutation in colorectal cancer. Nat Genet 38: 787-793.

Wikman H, Kettunen E, Seppanen JK, Karjalainen A, Hollmen J, Anttila S, Knuutila S. 2002. Identification of differentially expressed genes in pulmonary adenocarcinoma by using cDNA array. Oncogene 21: 58045813.

Wrage M, Ruosaari S, Eijk PP, Kaifi JT, Hollmen J, Yekebas EF, Izbicki JR, Brakenhoff RH, Streichert T, Riethdorf S, et al. 2009. Genomic profiles associated with early micrometastasis in lung cancer: Relevance of $4 \mathrm{q}$ deletion. Clin Cancer Res 15: 1566-1574.

Yagi K, Akagi K, Hayashi H, Nagae G, Tsuji S, Isagawa T, Midorikawa Y, Nishimura Y, Sakamoto H, Seto Y, et al. 2010. Three DNA methylation epigenotypes in human colorectal cancer. Clin Cancer Res 16: $21-33$.

Yoshikawa H, Matsubara K, Qian GS, Jackson P, Groopman JD, Manning JE, Harris CC, Herman JG. 2001. SOCS-1, a negative regulator of the JAK/ STAT pathway, is silenced by methylation in human hepatocellular carcinoma and shows growth-suppression activity. Nat Genet 28: 29-35.

Yue W, Dacic S, Sun Q, Landreneau R, Guo M, Zhou W, Siegfried JM, Yu J, Zhang L. 2007. Frequent inactivation of RAMP2, EFEMP1 and Dutt1 in lung cancer by promoter hypermethylation. Clin Cancer Res 13: 4336-4344.

Zhang W, Glockner SC, Guo M, Machida EO, Wang DH, Easwaran H, Van Neste L, Herman JG, Schuebel KE, Watkins DN, et al. 2008. Epigenetic inactivation of the canonical Wnt antagonist SRY-box containing gene 17 in colorectal cancer. Cancer Res 68: 2764-2772.

Received September 30, 2011; accepted in revised form April 9, 2012. 


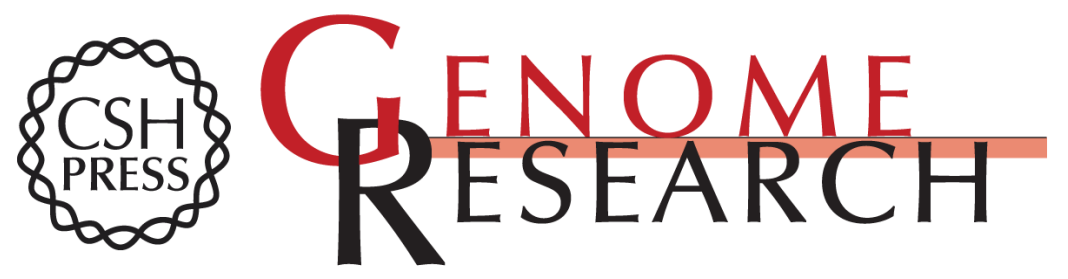

\section{Genome-scale analysis of DNA methylation in lung adenocarcinoma and integration with mRNA expression}

Suhaida A. Selamat, Brian S. Chung, Luc Girard, et al.

Genome Res. 2012 22: 1197-1211 originally published online May 21, 2012

Access the most recent version at doi:10.1101/gr.132662.111

\section{Supplemental http://genome.cshlp.org/content/suppl/2012/04/11/gr.132662.111.DC1 \\ Material}

Related Content Translating genomic information into clinical medicine: Lung cancer as a paradigm

Mia A. Levy, Christine M. Lovly and William Pao

Genome Res. November , 2012 22: 2101-2108

References This article cites 157 articles, 47 of which can be accessed free at:

http://genome.cshlp.org/content/22/7/1197.full.html\#ref-list-1

Articles cited in:

http://genome.cshlp.org/content/22/7/1197.full.html\#related-urls

Creative This article is distributed exclusively by Cold Spring Harbor Laboratory Press for the

Commons first six months after the full-issue publication date (see

License

http://genome.cshlp.org/site/misc/terms.xhtml). After six months, it is available under a Creative Commons License (Attribution-NonCommercial 3.0 Unported License), as described at http://creativecommons.org/licenses/by-nc/3.0/.

Email Alerting Receive free email alerts when new articles cite this article - sign up in the box at the Service

\section{Affordable, Accurate Sequencing.}

